\title{
Smelting in the Shadow of the Iron Mountain: Preliminary Field Investigation of the Industrial Landscape around Phnom Dek, Cambodia (Ninth to Twentieth Centuries A.D.)
}

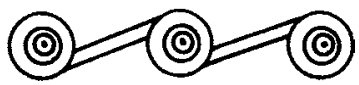 \\ Mitch Hendrickson, Stéphanie Leroy, Quan Hua, Phon Kaseka, \\ and Voeun Vuthy
}

\begin{abstract}
The high-grade mineral ores of the Phnom Dek region in central Cambodia have long been suspected of playing a major role in the rise of Angkor, the largest medieval polity in mainland Southeast Asia. This article presents the first comprehensive study by the Industries of Angkor Project (INDAP) to document the extent of industrial activity in this region and test this important relationship. Using a combination of intensive field survey, surface collection, and archaeometallurgical analysis, we evaluate the temporal and spatial patterning of iron production and the heterogeneity of smelting systems. The identification of at least three different smelting traditions has a significant impact on the current view that twentieth-century Kuay smelting practices extend deep into Cambodia's history, and their relationship with Angkor in particular. More broadly, the survey demonstrates the importance of Phnom Dek as a major production zone on par with more well-known examples in Roman Europe and Africa. Keywords: Angkor, iron metallurgy, industrial landscapes, mainland Southeast Asia, ethnic minorities.
\end{abstract}

\section{INTRODUCTION}

IRON IS ONE OF THE MOST UBIQUITOUS METALS ON EARTH, but abundant sources of high-grade iron oxide are significantly less common (Rostoker and Bronson 1990). Throughout history, states and expansion-minded polities have sought control over sources of iron oxide or production output (Cleere and Crossley 1985; de Barros 1986; Haaland 2014; Piétak et al. 2002; Schmidt 2009; Shinnie 1985). Depending on the quantity of smeltable ore, the exploitation of such areas can transcend multiple

Mitch Hendrickson is an assistant professor in the Department of Anthropology, University of Illinois at Chicago. Stéphanie Leroy is a researcher at LAPA-IRAMAT, NIMBE, CEA, CNRS, Université ParisSaclay France. Quan Hua is principal research scientist at the Australian Nuclear Science and Technology Organization (ANSTO). Phon Kaseka is director of the Archaeology Department at the Institute of Culture and Fine Arts at the Royal Academy of Cambodia. Voeun Vuthy is the head of the Department of Archaeology at the Ministry of Culture and Fine Arts in Cambodia. 


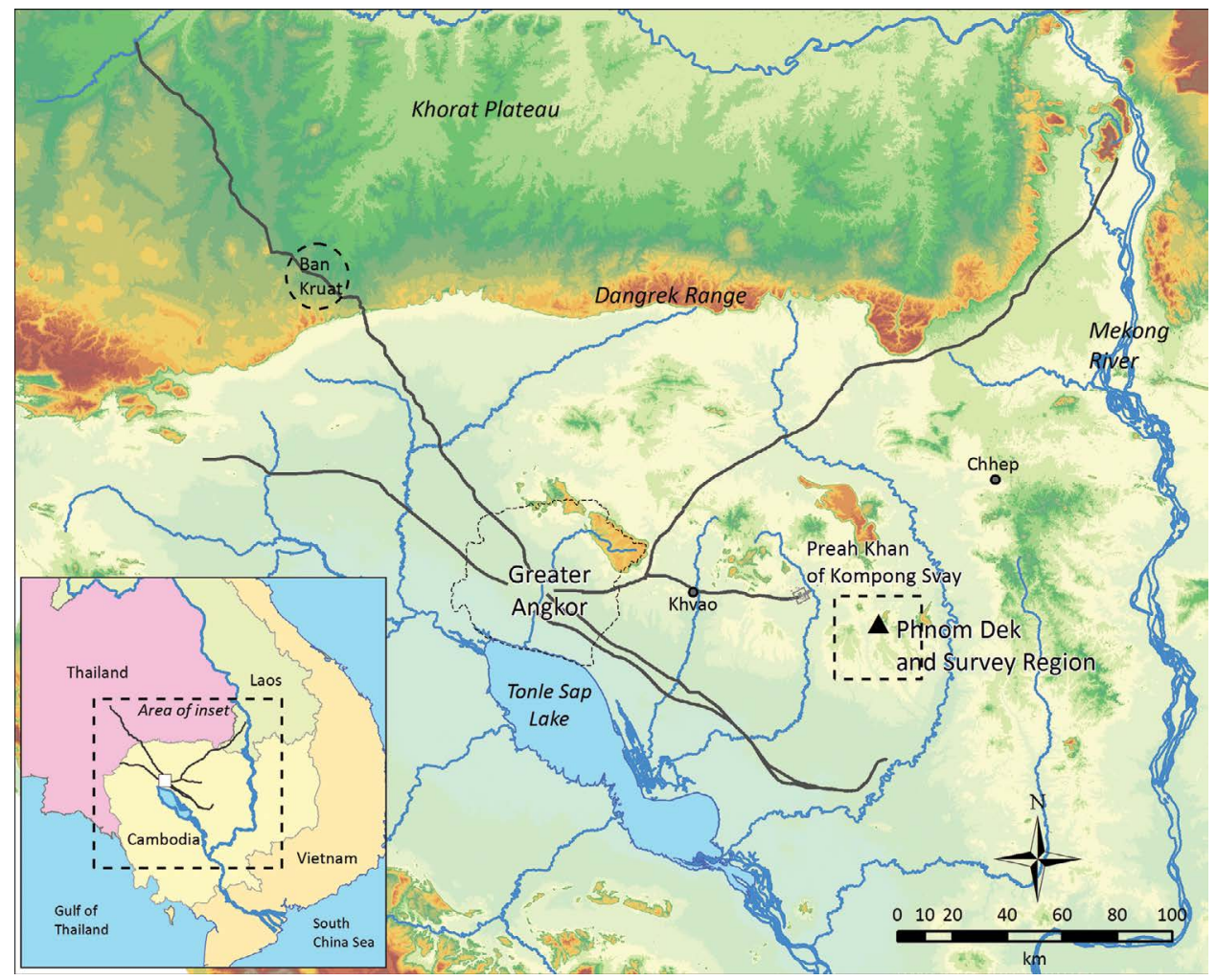

Fig. 1. Map of Cambodia showing the location of Phnom Dek, the Angkor road system and key sites, and settlements and iron production sites including Phnom Dek. Background DEM (Digital Elevation Model) derived from SRTM $90 \mathrm{~m}$ data set, available at http://www.cgiar-csi.org/data/srtm-90m-digitalelevation-database-v4-1.

time periods, resulting in the generation of massive, complex industrial landscapes. Phnom Dek (lit. "Iron Mountain") in Preah Vihear, Cambodia, represents the most significant supply of high-grade iron ore in the Lower Mekong catchment (Fig. 1). This region has become a major focal point in theories related to the timing of the expansion of the Angkorian Khmer Empire. One of Angkor's main roadways (ninth to fifteenth centuries A.D.) may have been placed there to provide access to the iron ore (Dupaigne 1987; Hendrickson 2011; Hendrickson and Evans 2015; Thuy 2014). Phnom Dek is also home to the "Iron Kuay," an ethnic minority historically known to have smelted direct bloomery iron from at least the sixteenth until the early twentieth century (Dupaigne 1987; Jacques and Lafond 2004). An initial study by the Iron Kuay Project (IKP)/Industries of Angkor Project (INDAP) of production sites in this region identified the presence of two potentially related technological systems spanning the tenth to twentieth centuries A.D. (Pryce, Hendrickson, et al. 2014).

The current study continues the investigation of the significance of Phnom Dek by, first, evaluating the spatiotemporal extent and scale of iron production within the industrial landscape and, second, expanding knowledge of the technological systems and testing their degree of homogeneity. Lacking direct evidence of furnace con- 
struction or detailed historic records, we employ a comprehensive approach using multiple technological traits visible from surface survey (i.e., mound morphology, furnace components, slag chemistry) integrated with slag chemistry analysis and in-slag AMS radiocarbon dating. Studying these numerous traits at the landscape scale enables us to consider changes in production and the nature and organization of smelting communities. It is further hoped that our multidisciplinary approach suggests a more feasible way of collecting meaningful information about metallurgical practices than methods that are completely reliant on intensive and expensive analytical protocols.

\section{IRON IN SOUTHEAST ASIA}

Metallurgy is a relatively new focus for prehistoric and historic archaeologists in mainland Southeast Asia. Substantial advances have been made in copper-base archaeometallurgy over the past three decades (Pryce, Baron, et al. 2014; Pryce, Bevan, et al. 2011; White and Hamilton 2009; White and Pigott 1996), but comparable interest in ferrous technologies remains limited. Iron as a material first appeared within burial and habitation contexts across the region between the fifth and fourth centuries B.C. However, publications on prehistoric iron use have been limited to documenting the presence of iron products such as tools, weapons, and ornaments. Only in the last few years have archaeometallurgical analyses become more frequently incorporated into research projects (e.g., Biggs et al. 2013; Murillo-Barroso et al. 2010). Perhaps most significantly, very few prehistoric iron production sites have been identified and even fewer have been excavated and properly dated (Nitta 1997; Venunan 2016).

The study of prehistoric iron sites has in part been limited by the small number of trained archaeometallurgists, but also by the lack of visibility of prehistoric production sites, which is necessary for revealing critical aspects of technological origin and development. The difficulty in finding prehistoric smelting sites is likely due to relatively little need for iron at the household and community levels. Evidence of production may not be found around large-scale sources if such small groups could have relied on the relatively abundant, low-quality sources of iron oxide found within lateritic deposits (Pryce and Natapintu 2009). Pryce and Natapintu (2009:259) point out that while laterite is a potentially viable source, the production of large quantities of iron requires richer mineral sources.

Recent research within the early historic period (from the fourth or fifth to fifteenth century A.D.) has greatly surpassed our knowledge of prehistoric iron production. Excavations in Myanmar (Hudson 2006, 2012; Hudson et al. 2001), Malaysia (Mokhtar et al. 2011), Laos (Pryce, Chiemsisouraj, et al. 2011), and Thailand (Suchitta 1983; Venunan 2011, 2016) have established a baseline understanding of dated furnace structures and compositional characteristics of individual technological systems. Landscape-scale surveys have yet to be completed to determine whether these sites were part of large industrial landscapes and whether they focused around specific mineral ore deposits. More importantly, current evidence is insufficient to begin making connections between metal production and the needs of early Southeast Asian states such as Pyu, Bagan, or Dvaravati.

We now turn our attention to evidence of iron in Cambodia, the heartland of the Angkorian Khmer Empire. 
IRON IN CAMBODIA: SOURCES

Mid-twentieth-century geological surveys revealed the presence of a handful of relatively small mineral deposits scattered around the Tonle Sap basin (Dottin 1971). As noted above, laterites and small, possibly exhausted, deposits of iron oxide were likely used in the past, but these could not support long-term production or satisfy statelevel demand. The richest deposits of ore in Cambodia are found in the Phnom Dek region. Composed largely of high-grade magnetite and hematite, Phnom Dek and several nearby hills represent a suitable resource for large-scale exploitation. Early colonial accounts noted traces of "ancient" mining around Phnom Dek (Dottin 1971 : 40-41). Recent work by INDAP at Tonle Bak and Sanlong Jaya confirmed that ore from the iron mountain was being exploited in nearby production contexts (Pryce, Hendrickson, et al. 2014). It remains to be determined whether Phnom Dek provided the bulk of the iron consumed by Cambodia's early states.

\section{IRON IN CAMBODIA: EVIDENCE}

The evidence for iron production and consumption in Cambodia varies considerably between Iron Age (fifth century B.C. to fifth century A.D.), early historic (fifth to fifteenth centuries A.D.), and recent ethnographic contexts. Iron Age cemeteries in northwest Cambodia contain substantial quantities of iron weapons, tools, and ornaments, but no traces of local production have been identified around these large, mounded occupations (O'Reilly et al. 2006). These objects may have come from the smelting sites found during surveys along Angkor's Northwest and West roads (LARP 2008). While dating has yet to be completed for the Cambodian sites, studies have shown that the Ban Kruat smelting loci in Northeast Thailand were operating during the late Iron Age (Venunan 2016:196-203). Recent research near Chhep in Northeast Cambodia appears to have identified evidence of prehistoric smelting, though further investigation is required to test the somewhat tenuous thermoluminescence results (Thuy 2014:39). The absence of excavation, survey, or analysis of prehistoric metallurgy sites is linked to the same issues found in other parts of Southeast Asia. As a result, it is difficult to use prehistoric evidence of iron smelting as a mechanism for evaluating technological ancestry and resource procurement practices. What is apparent is that there are no known prehistoric settlements or production sites in the Phnom Dek region.

Iron would have been a key resource in facilitating the agricultural, architectural, and military objectives of early Cambodian states during the pre-Angkor (sixth to eighth centuries) and Angkor (ninth to fifteenth centuries) periods. The Angkorian Khmer Empire, based at the capital city of Angkor, became the dominant polity across the region. It is hypothesized that iron enabled the Khmer to expand their territory and build massive temples and hydraulic works. Iron weapons and tools are often recovered in excavation of settlements and temples and iron armatures are present inside bronze religious statuary made with the lost-wax process. The richest source of iron artifacts are the architectural clamps or crampons recovered from masonry temples in Angkor and peripheral complexes across Cambodia, Northeast Thailand, and southern Laos. Studies intended to identify the composition, source, and morphology of iron objects and new approaches to radiocarbon dating their production 
are providing new insights into consumption practices of the Angkorian Khmer (Leroy et al. 2015).

While evidence of iron use continues to increase throughout the historic periods, we have yet to find any production sites that can be specifically dated to the preAngkor era. Earlier smelting activities may yet underlie the numerous mounds found in proximity to the road system (Im 2011; LARP 2008), inside the temple complex of Preah Khan of Kompong Svay (henceforth Preah Khan) (Hendrickson et al. 2013), and around Phnom Dek (Dupaigne 1987; Hendrickson and Pryce 2011; Thuy 2010). Currently, the radiocarbon dates from smelting sites associated with the Angkorian period are clustered toward either the early (ninth century) or late Angkor to postAngkor production (thirteen to sixteenth centuries). Only one slag concentration found in Preah Khan actually corresponds to Angkor's expansionist phase between the eleventh and thirteenth centuries (Hendrickson et al. 2013).

Of these three regions, Phnom Dek appears to have the largest and densest evidence of metallurgical activity. Excavation at Phnom Dek and Preah Khan has yet to locate intact furnace structures, but the study of the tuyère form shows at least two different technological systems (Pryce, Hendrickson, et al. 2014). Preliminary compositional analyses of slag, technical ceramics, and ores have also demonstrated that Phnom Dek ore was used from the ninth through to the twentieth century. This temporal connection to the modern era leads us to consider ethnographic evidence of the "Iron Kuay" people.

The Kuay people are an ethnic minority with a long-established connection to bloomery iron smelting around Phnom Dek. Ethnohistoric records of Kuay peoples (Duffosé 1934; Dupaigne 1987; Harmand 1876; Lévy 1943) have arguably been most influential in framing the development of historic-period iron in Cambodia. The earliest textual evidence of Kuay ironworking appears in a sixteenth-century chronicle of Cambodia. A passage dated to 1533 states that King Ang Chan I ordered a pond to be constructed north of a hill at Oudong, near which the Kuay established a foundry to manufacture arms (Khin 1988:151). The value of Kuay iron is further attested in a nineteenth-century report describing the annual expedition of traders from Stung Treng to Phnom Dek to obtain ingots of high-quality Kuay metal (Harmand 1876:348). This tradition continued until the mid-twentieth century, but then became uneconomical following the introduction of large quantities of inexpensive foreign steel.

Our knowledge of Kuay furnace technology is based on early French colonial accounts (Duffosé 1934; Harmand 1876) and the more recent and extensive ethnohistoric work of Dupaigne (1987). From these reports we know that the Kuay employed a forced-draft bloomery smelting technique. Furnaces were constructed of clay supported by bamboo lattices. Each furnace was pierced with up to 26 clay tuyères on either side; air was pumped into the furnace via a bellows made of animal hide (Duffosé 1934; Harmand 1876:561). Dupaigne's detailed interviews with Kuay smelters in 1969 (over 20 years after they ceased to produce iron) provides intriguing insight into their ritual practices as well as resource procurement and alignment and organization of furnaces (Dupaigne 1987:206).

Given the lack of a comparable knowledge system recorded for Khmer culture, Dupaigne (1987) advanced the deep history of the Kuay tradition as a direct window into the social and technological practices of Angkor's past. While ethnographic 
records offer a useful foundation for evaluating past traditions, a vast literature cautions against drawing direct analogies between present and past metallurgical practices (Kramer and David 2001). A classic example of this problem is noted in discussing the exceedingly rich ethnographic and archaeological evidence for iron metallurgical systems in sub-Saharan Africa: "Ethnography by itself may encourage the notion of continuity over countless centuries; but, without an archaeological perspective with dated examples, we are in no position to confirm or discuss this, to tell in effect how traditional is "traditional"' (Sutton 1985:178). Within the context of Angkor iron production, it is therefore necessary to evaluate the depth of technological continuity with the Kuay tradition and whether the Kuay tradition is an ancestor to the smelting practices of Cambodia's early state.

An initial test of this relationship was conducted by IKP and INDAP using a combination of surface surveys, test excavation, artifact analyses, and AMS radiocarbon dating (Pryce, Hendrickson, et al. 2014). The results revealed smelting sites with at least two distinct tuyère morphologies or gauges, defined by the relative size of the bore hole and clay thickness. The medium gauge tuyères are associated with production from the peak through to the decline of Angkor (eleventh to sixteenth centuries) and the thin gauge with ethnohistoric Kuay. A third type with broad gauge tuyères found at Tonle Bak 1 (STB-01) also appears to be associated with early Angkor (ninth to eleventh centuries). Unfortunately, the measurements for these tuyères were derived from broken fragments and no complete tuyères were recovered at the site (Pryce, Hendrickson, et al. 2014). Morphological differences aside, analysis of slag and mineral chemistry demonstrated that both Angkor (Tonle Bak) and Kuay (Sanlong Jaya) sites utilized ore from nearby Phnom Dek and that the smelting recipe showed a basic chemical consistency through time. A more robust evaluation of spatiotemporal variation in both technological systems and chemistry is needed to determine the degree of interrelationship between Angkor and Kuay traditions.

\section{DOCUMENTING IRON PRODUCTION}

A methodology for effectively locating, recording, and interpreting iron production sites has yet to be properly developed and tested within Southeast Asia. Fortunately, the extensive work conducted in sub-Saharan Africa, India, and Europe allows us to avoid the academic growing pains of choosing field data suitable for addressing a broad array of technological and cultural issues. Knowledge of iron production practices is clearly outlined from living ethnographic traditions and detailed historic records (Childs 2000; Iles and Childs 2014; Schmidt 2009). Unfortunately, these sources are not available everywhere iron was produced and, as noted above, they have a limited interpretive time-depth for studying the development of specific iron industries (Killick 2009). We therefore direct our attention to the most visible element of the smelting process, the furnace.

Decades of prior research on furnaces has demonstrated two important considerations when developing a framework for survey and investigation: 1) we should expect considerable variability in the organization and arrangement of furnace structures; and 2) the nature of the archaeological remains of smelting systems will be exceedingly dynamic (Sutton 1985). Initial studies in Africa focusing on furnace shape and size, while informative, were seen as too limited to be emulated here, especially as 
they required inclusion of traits such as types of slag, charging arrangements, air supply, and slag disposal (Pole 1985). Many of these features are only visible from ethnographic data sets. More practically, the emphasis on furnace form as a primary data set usually relies on expensive and time-consuming excavation.

Another issue is that it is often difficult to clearly identify furnace structures because they are damaged by taphonomic processes or destructive extraction of the bloom (Elwin 1942:239; Hodgkinson and Tebutt 1985). In Cambodia, test excavations of large slag concentrations by IKP/INDAP discovered repeated layers of wall fragments and smelting debris, but little coherent evidence of actual furnaces, suggesting that furnaces were indeed destroyed to extract the bloom (Pryce, Hendrickson, et al. 2014).

A more effective approach for documenting numerous iron production sites within a region is to shift focus from the furnace to the slag concentration or mound. Like individual furnaces, the size and form of a slag concentration is a proxy for a metallurgical practice at a single location over time. Size and shape can inform us about the number of smelting episodes as well as the organization of spaces of production. Recent work at Meroe in northern Africa successfully applied multiple techniques (i.e., geophysical, excavation, quantitative) to document the structure of a large mound in the capital (Humphris and Carey 2016). These labor-intensive tests are effective, but unsuitable for documenting large numbers of sites across a vast landscape. Modeled on a methodology used in the Bassar region of West Africa (de Barros 2000; Robion-Brunner et al. 2013), we adopted a holistic, descriptive, and analytical investigation of slag concentrations across the Phnom Dek region.

Slag concentrations are often littered with metallurgical residues from all parts of the smelting system, including technical ceramics such as the furnace wall and tuyères, fuel, slag, and gangue mineral or ore. Such residues provide technological insight into individual concentrations and groups of concentrations. The quantity and diversity of such residues vary depending on technological tradition and taphonomic processes. For instance, while furnace wall fragments are often too small to be informative, the more durable tuyères can be important markers of social, spatial, and temporal patterning (Sutton 1985). As a critical part of the air-delivery system, and one that is more readily preserved than bellows systems, the dimensional characteristics and quantities of tuyères provide insight into the organization and output of furnaces. Fuel sources such as fragile pieces of charcoal are another critical part of the production process, but are unlikely to survive on the surface of concentrations and are more prone to be translocated by monsoon rains.

The most informative component for research is slag. This extremely durable material appears in multiple forms (i.e., smelting, tap, or smithing) that can inform us about the furnace structure, stages of production, and output. Archaeometric investigations of slag morphology, microstructure, and chemistry can help us analyze different aspects of the chaîne opératoire (operational sequence) and smelting processes. Combined with archaeological context, analyzing slag enables us to understand technological aspects of furnaces, modes of production, resource procurement, and the development of ironworking through time (Ploquin 1994; Serneels 1993a). More specifically, slag can provide insight into determining the smelting recipe[s] of the producers (Rehren et al. 2007). By studying the chemistry of smelting slag-which contains remnant signatures of iron ores, technical ceramics, furnace-building materials, and fuels - it becomes possible to identify different groups of bloomery furnace 
iron producers. Sampling slag from large numbers of industrial sites then enables us to identify shifts in spatiotemporal preferences or the presence of different technological traditions (Charlton et al. 2010).

A multi-scalar, analytical investigation of slag concentrations provides an effective means for collecting data that will enable us to address patterning across a metallurgical landscape. Returning to the African baseline studies, Sutton $(1985: 174)$ pointed out the importance of recognizing the interdependence of variables within a smelting system and how they change to meet demands based on local conditions and idiosyncratic aspects of culture. Ultimately, the comparison of components within their ecological and cultural milieu in Southeast Asia will allow us to consider archaeologically intangible factors, such as who was responsible for smelting the iron.

\section{SURVEY}

One of the priorities of this article is to present a field approach incorporating basic archaeometallurgical analysis. Our methodology proved an efficient and relatively cost-effective means for documenting and describing some aspects of iron production in Cambodia. Based on this work, we reveal information about the technological practices, chronology, spatial organization, and possible existence of different smelting groups. It must be noted that this represents a first step that will anchor a broader, more intensive approach currently being undertaken by the INDAP team.

Prior to arriving in the field, a base map of potential production loci was generated to guide the ground survey. New sites were identified by tracking the signatures of previously studied mounds (typically large clusters of trees in agricultural fields) using GoogleEarth and IKONOS in ArcGIS 10.2. We also incorporated data from previous surveys (Dupaigne 1987; Thuy 2014) into the digital map along with proximity to known Kuay villages (Seidenfaden 1952). While in the field, we used a Trimble Juno 5 Series GPS.pr to record the spatial location and dimensional characteristics of each slag concentration during our walking surveys.

Determining mound morphology was key to assessing the organization and intensity of smelting at each location. After completion of our field survey, we identified five different slag concentration profiles: flat scatters and simple, raised, ridged, or irregular mounds (Fig. 2). Flat concentrations are scatters of industrial debris that have little relief above the ground surface. The four remaining categories reflect various ways industrial debris was mounded and inform on smelting processes from a macrolevel perspective. Simple mounds are uniform heaps of industrial debris. Raised mounds have a directional slope on one side of the concentration. Ridged mounds are simple mounds that have a bank of material on one side of the concentration. Irregular or raised mounds have undulating surfaces and often display a depression in the center.

The team visited and recorded data from 14 sites over a period of 8 days. This total comprised 73 individual slag concentrations in regions to the west, south, and east of Phnom Dek (henceforth PD West, PD South, and PD East; Fig. 3). This likely represents only a partial inventory of metallurgical sites, as forest coverage and the danger of crossing land where there might be unexploded ordnance (UXO) and land mines inhibited comprehensive field survey. Surface collections from each mound ideally included a maximum of five to ten tuyères, five small fragments of slag, and one or more large tap slag cakes. 


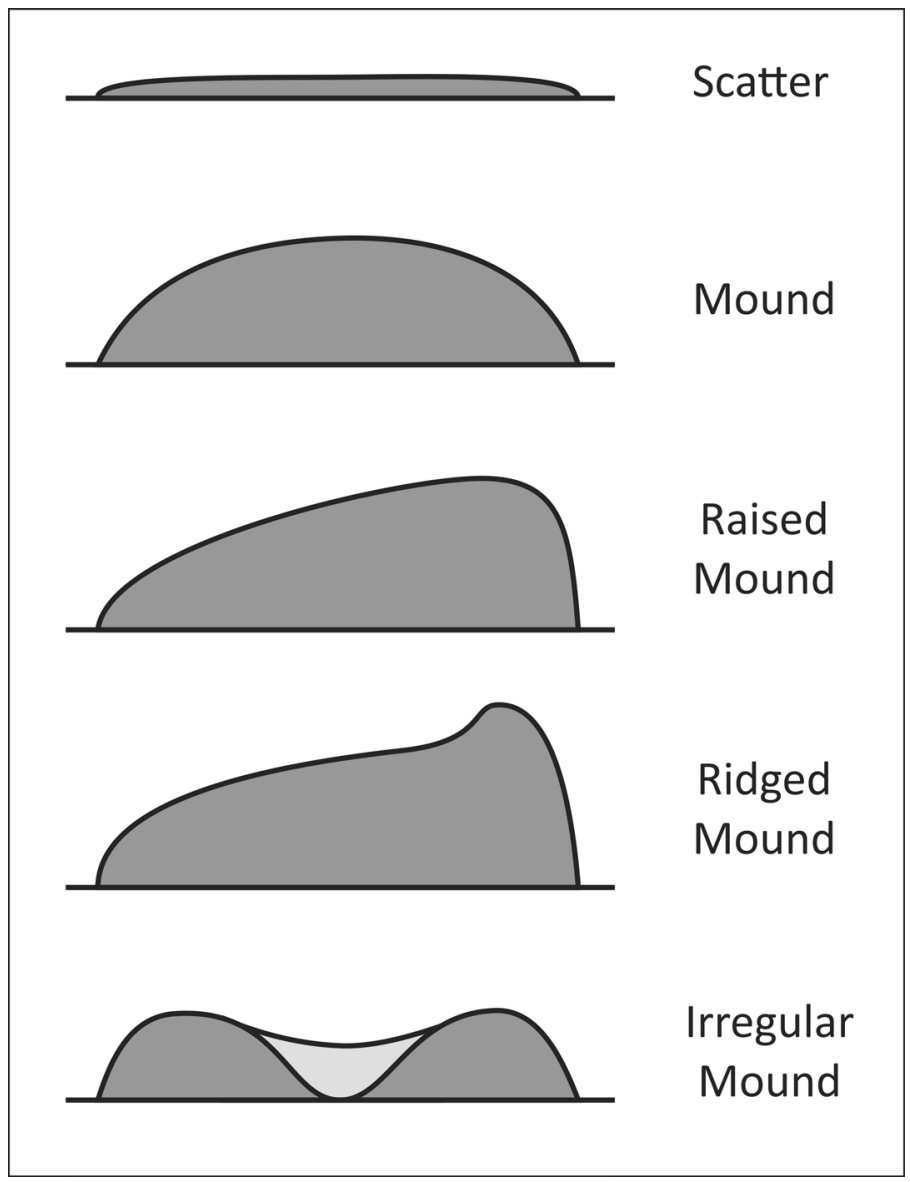

Fig. 2. Slag concentration profiles identified in the Phnom Dek region.

\section{Phnom Dek West}

We concentrated survey west of Phnom Dek along roads and paths in the vicinity of Svay Damnak village, one of the last remaining isolated Kuay communities in the region. Site location in this zone was delimited by dense forest and uncertainty about clearance of UXO and land mines. Five iron-production sites were identified with each containing from one to four individual slag concentrations: Trapeang Sanlong (STS), O Rumchek (SOR), Russei Prei (SRP), Svay Damnak Thmei (SDT), and Sre Po (SSP) (Fig. 4).

With the exception of the Trapeang Sanlong mound (STS-01), which is near the bank of a typical Angkor period reservoir, the slag mounds are not found in association with cultural infrastructure or ceramic concentrations. Svay Damnak Thmei and Sre Po are respectively situated inside and adjacent to the modern settlement of Svay Damnak village, but are not spatially or temporally related to it (Fig. 4). The size of the mounds in region west of Phnom Dek are relatively modest, with the highest mounds at Svay Damnak Thmei and Sre Po extending up to a maximum of $1.8 \mathrm{~m}$ in 


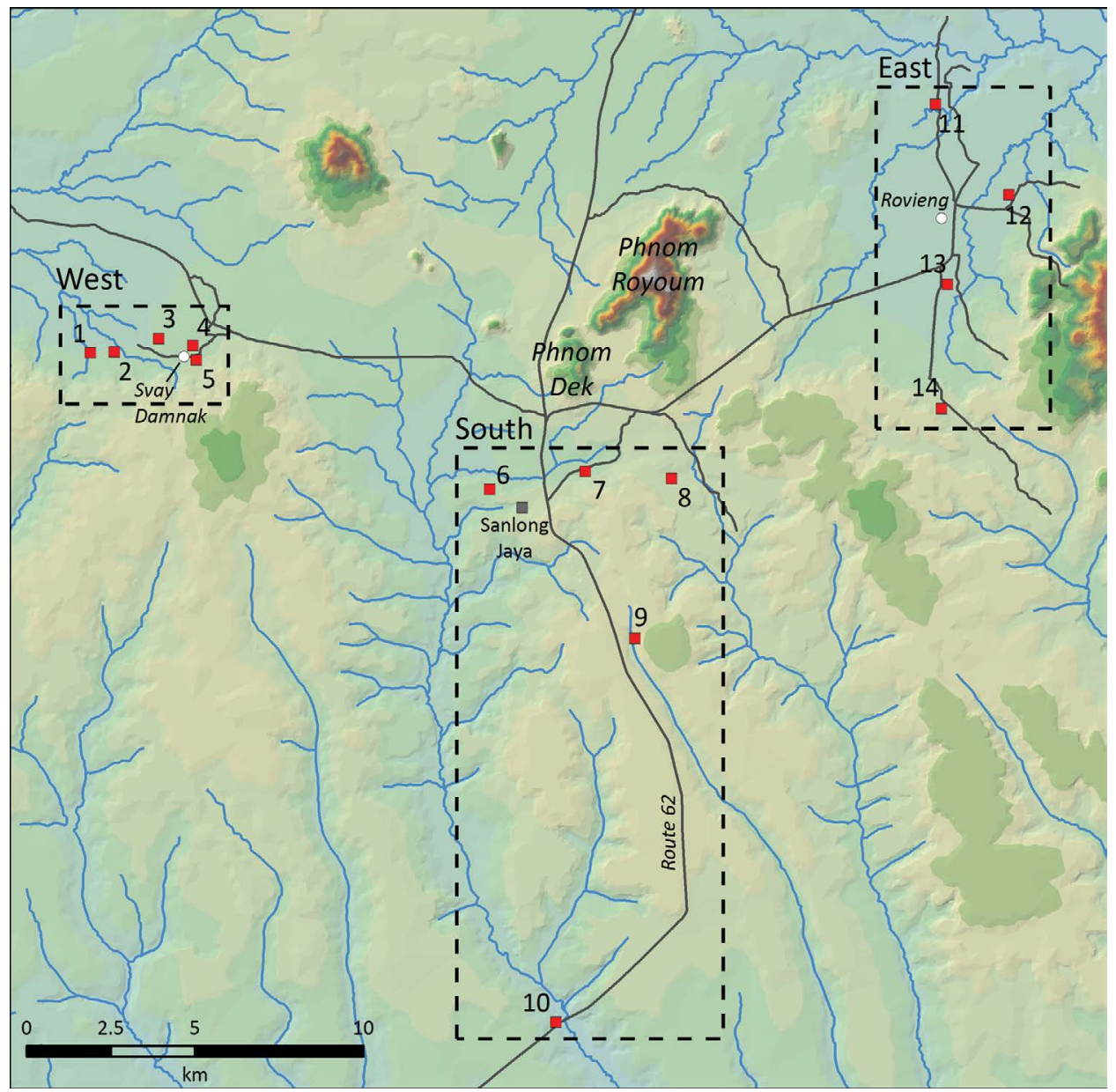

Fig. 3. Location sites surveyed during 2013 field campaign. Western zone: 1) Trapeang Prasat; 2) O Rumchek; 3) Russei Prei; 4) Svay Damnak Thmei; 5) Sre Po, Southern zone: 6) Prei Russei; 7) Tonle Bak; 8) Chhay; 9) Cham; 10) O Pou, Eastern zone: 11) Boeng; 12) Ta Tong; 13) Rung Reung; 14) Phum Sanlong. Darker tones represent higher elevations. DEM derived from JICA (Japan International Cooperation Agency) GIS topography data set.

height. Thin tuyères were found at Sre Po, Svay Damnak Thmei, and O Rumchek, while medium ones were clustered farther west at Russei Prei and Trapeang Sanlong.

\section{Phnom Dek South}

Sites in the region south of Phnom Dek can be divided into two groups based on their relative proximity to the mountain. The group closest to Phnom Dek includes Prei Russei (SPR), Tonle Bak (STB), and Chhay (SCH). These sites are characterized by densely arranged clusters of industrial material with individual mounds exceeding $2.5 \mathrm{~m}$ in height. Prei Russei is a remote set of four high mounds situated around small, unformalized ponds (Fig. 5). To the north and west of the metallurgy sites is a 100-m-long rectangular trapeang and the remains of a brick temple known locally 


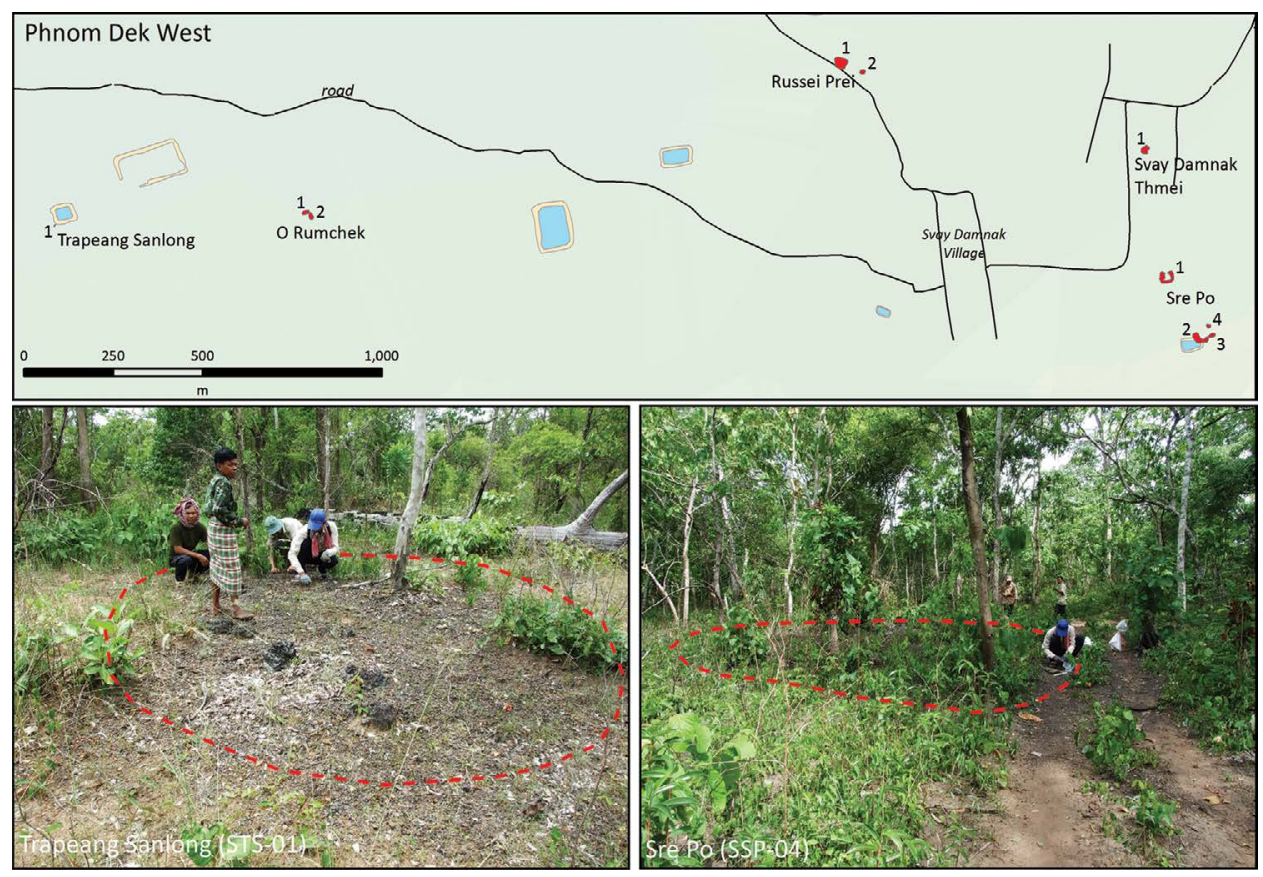

Fig. 4. West Phnom Dek: distribution of slag concentrations in the vicinity of Svay Damnak and Svay Damnak Thmei villages. Images show size of mounds and vegetation coverage at Trapeang Sanlong (STS-01) and Sre Po (SSP-04).

as Prasat Boran that likely dates to pre-Angkor or early Angkor periods. While the tuyères at Prei Russei are medium gauge (correlating to Angkor and post-Angkor periods), there does not appear to be any spatial correlation to suggest the metallurgy sites are contemporary with the religious infrastructure.

Tonle Bak ("Broken Lake") is another dense group of slag concentrations situated west of a low-banked 240-m-long reservoir. Initially surveyed in 2010, Tonle Bak is the closest iron-production site to Phnom Dek. Previous excavation of an isolated mound (STB-01) north of the main group of concentrations revealed that smelting had occurred during the ninth to eleventh centuries (Pryce, Hendrickson, et al. 2014 : 146). The slag mounds clustered to the west of the reservoir include STB-02, a massive mound spanning $50 \times 40 \mathrm{~m}$ and ascending up to $6 \mathrm{~m}$ above the surrounding rice fields (Fig. 5, mound 2). Beyond the large scale of the slag concentrations, Tonle Bak is the only metallurgy site in the Phnom Dek region with any evidence for what may be contemporary settlement. The low-lying area between STB-05 and STB-07 is littered with Angkor-era ceramics, including Khmer brown-glazed stone wares and Chinese imports (Fig. 6). The density and diversity of sherds near the large reservoir also suggest the presence of a relatively permanent population. The correlation of these features requires us to consider whether this was a non-Khmer smelting community actively participating within the broader Angkorian trade system or the producers were actually Khmer. Tonle Bak therefore represents one of the best sites to address questions about furnace operation and the lifeways of those who produced iron. 


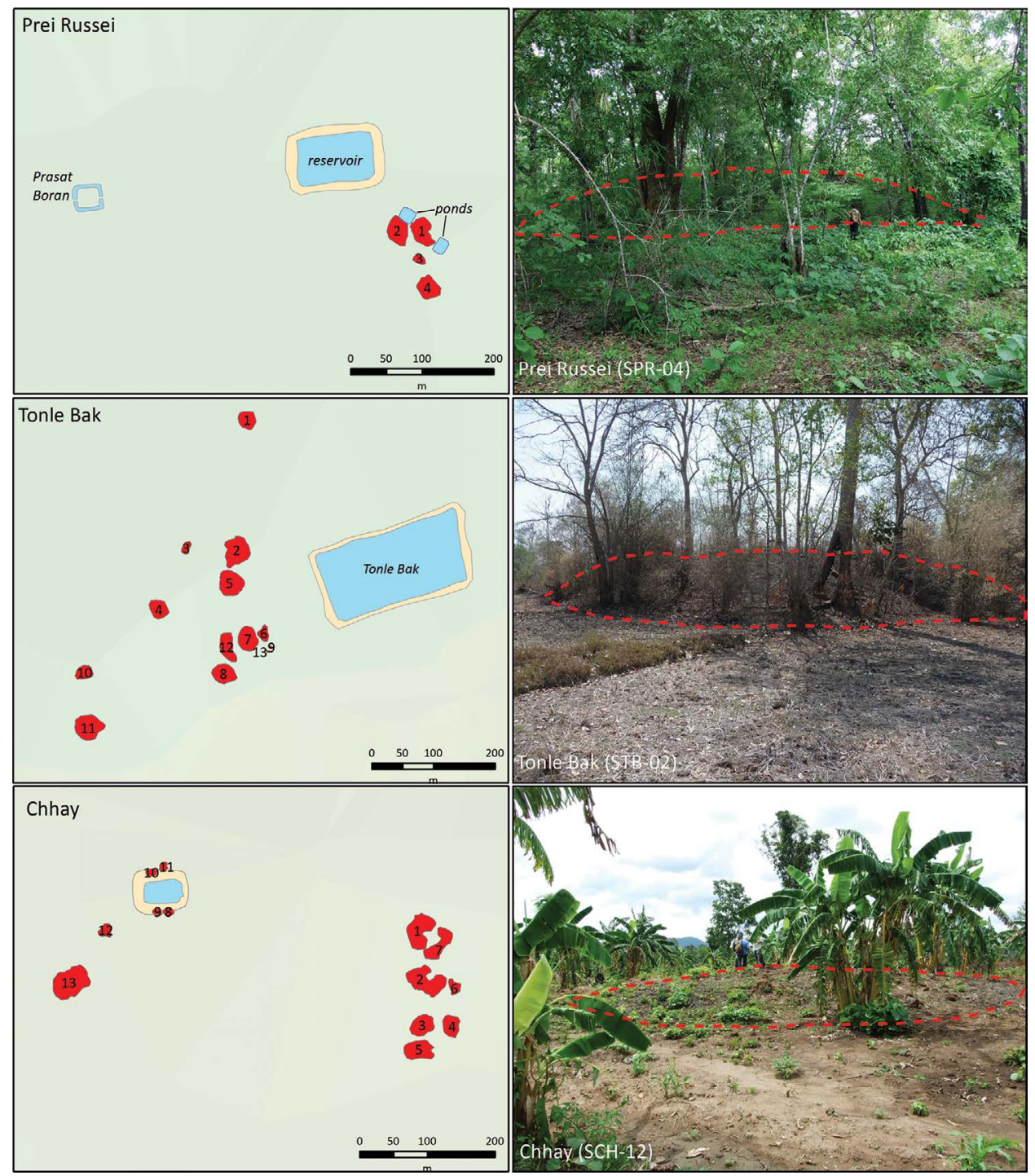

Fig. 5. South Phnom Dek: distribution of slag concentrations at Prei Russei, Tonle Bak, and Chhay. Images show size of mounds and vegetation coverage at Prei Russei (SPR-04), Tonle Bak (STB-02), and Sre Po (SSP-04).

The Chhay site was initially visited in 2010, but recent agricultural clearing of the forest allowed us to record five more mounds to the west of the main cluster (Fig. 5). The east group contains seven separate concentrations interspersed between what appear to be small ponds; the concentrations range in height from 1.0 to $1.8 \mathrm{~m}$ above ground level. Thin tuyères are the predominant form in this group with the exception of mound 4 ( $\mathrm{SCH}-04)$, which has medium tuyères. The new sites along the trapeang are small scatters with thin-gauge tuyères, while those in the newly estab- 


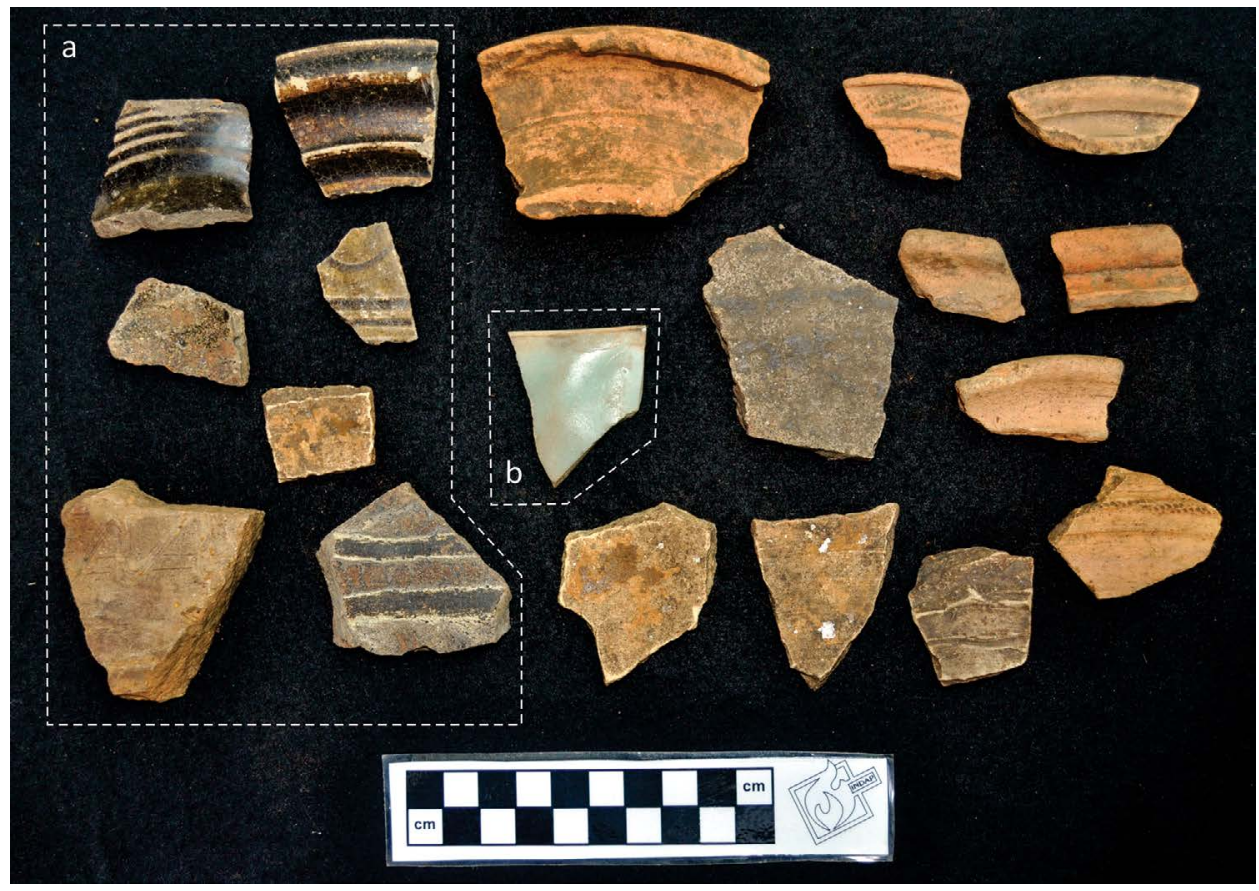

Fig. 6. Ceramics from occupation area between mounds 5 and 7 at Tonle Bak. Presence of a) typical Khmer brown glazed stonewares and b) Chinese green-glazed porcelain indicate interaction with Angkorian trade system. Remaining (uncircled) types are earthenwares.

lished banana plantation to the southwest alternate between thin- or medium-gauge tuyères.

Cham (SCM) and O Pou (SOP) represent the farthest known evidence of iron production in the south region (i.e., $8 \mathrm{~km}$ and $19 \mathrm{~km}$ ). Cham is a single mound located c. $500 \mathrm{~m}$ east of Route 62 along the former French colonial route to the district capital of Rovieng. Slag was extremely scarce across this broad concentration but the surface was littered with the long examples of thin-gauge tuyères. According to local villagers the site received the name Cham as it was apparently operated by members of the predominantly Muslim minority group based in southern Viet Nam and Cambodia. Beyond the length of the tuyères there is no other apparent difference between this mound and others in the region. O Pou is a Kuay village on Route 62 that contains one low mound with thin tuyères located on the edge of a house plot. Locals reported the presence of numerous smelting sites north along the $\mathrm{O}$ Pou River but there was insufficient time to visit these locations. The village was also home to one of the last remaining chhay, or master smelters, who unfortunately died in 2007.

\section{Phnom Dek East}

Data collection to the east of Phnom Dek focused on four sites: Boeng (SBO), Ta Tong (STT), Rung Reung (SRR), and Phum Sanlong (SPS). Unlike the more 
densely forested areas to the south and west, the landscape here is more heavily focused on rice agriculture, which produces both positive and negative impacts for survey. Deforestation makes identification of mounds much easier as farmers must avoid the dense slag heaps when creating new paddies. However, cutting and clearing edges of mounds can alter the extent of concentrations and there is the potential for early and late materials being piled and mixed on the surface. To avoid this latter issue during the survey, sample selection was restricted to the very top of mounds.

The greatest quantity of slag concentrations across all three study areas is found at Boeng (Fig. 7). This site is more accurately divided into two groups (east and west) based on proximity to a trio of large reservoirs (boeng in Khmer) and an eleventhcentury temple known, unsurprisingly, as Prasat Boeng. The east group consists of nine individual concentrations established on the banks of the largest reservoir. The concentrations are $0.8-2 \mathrm{~m}$ high and have medium-gauge tuyères. Mound 9 (STB-09) is the only mound located on the west side of the reservoir and was recently bisected during road construction work. The resulting cross section shows a similar overlaying of waste products and refractories found in previous excavations. This allowed a unique opportunity to vertically sample slag, tuyères, and charcoal for analysis.

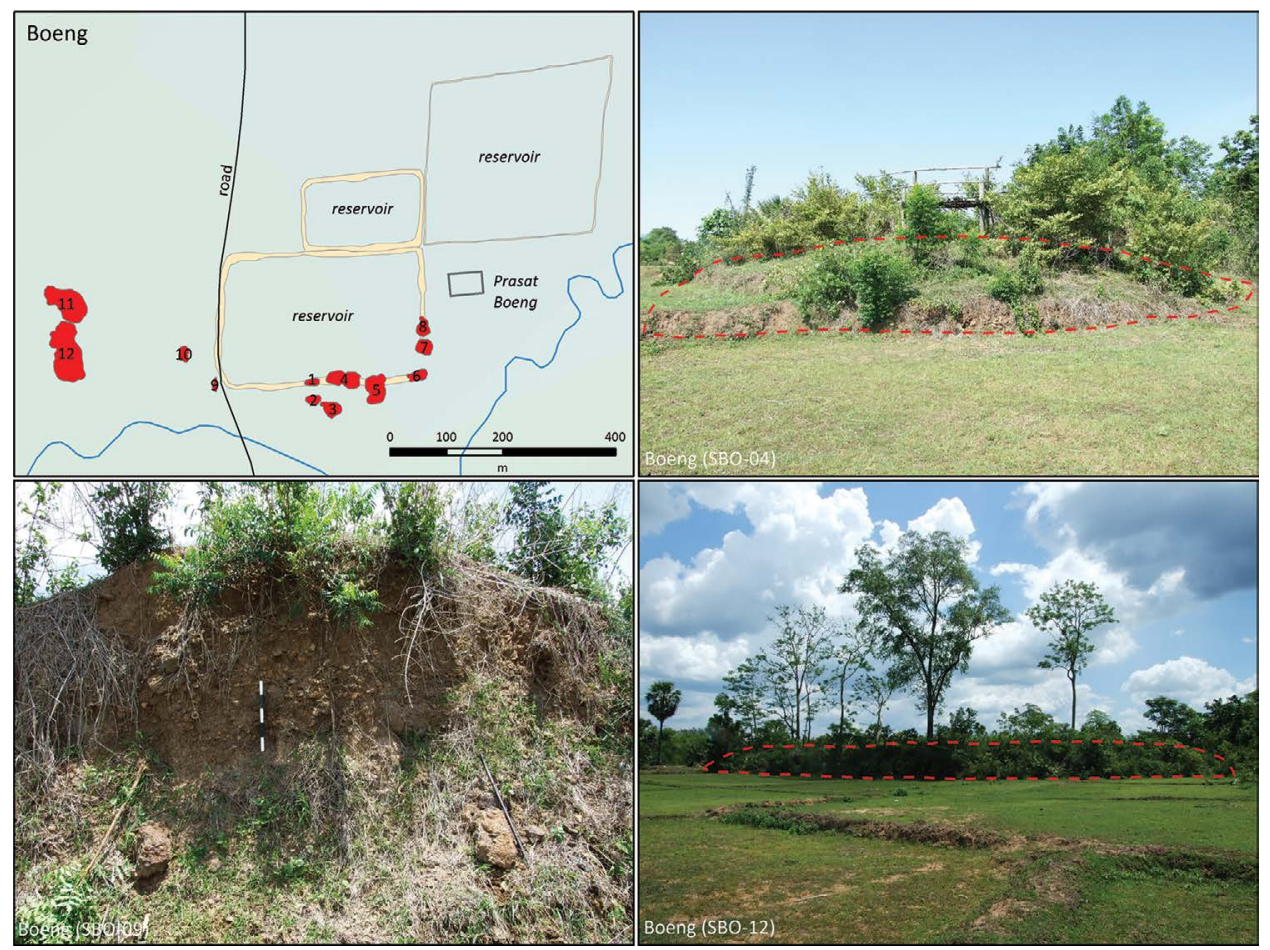

Fig. 7. East Phnom Dek: distribution of slag concentrations at Boeng (upper left); Eastern group (1-9) clustered around southern reservoir; Western group (10-12) situated in rice fields west of the roadway; mound SBO-04 cut by rice-farming activity (upper right); road cut through mound SBO-09 displaying deposit of mixed metallurgical debris (lower left); view of mound SBO-12, with maximum height of $4.5 \mathrm{~m}$ (lower right). 
Boeng west is marked by two massive concentrations, including SBO-12, a mound rising $4.5 \mathrm{~m}$ high and stretching over an $110 \mathrm{~m} \times 48 \mathrm{~m}$ area. In addition to the immense size of these mounds, several other traits distinguish Boeng west from other sites. The slag on the surface and in looting pits is characterized by a green-gray surface color and has a linear or grasslike pattern on one side. This slag is densely scattered and packed on the surface and inside looters' pits; there are no large slag cakes. Perhaps most importantly, the only tuyères found were at the base of mound SBO-11. These tuyères are much larger than the medium-gauge examples. They may relate to the technological system indicated from fragmentary examples excavated by IKP at Tonle Bak (STB-01) (Pryce et al. 2014).

The other three sites in the eastern zone (Ta Tong, Rung Reung, Phum Sanlong) are notably smaller than those at Boeng, but demonstrate a remarkable diversity of smelting practices. The sites associated with Ta Tong are broadly scattered across an area of open rice fields (Fig. 8). These sites are not associated with any Angkor infrastructure and are positioned between small rivers to the west and east. Each of these

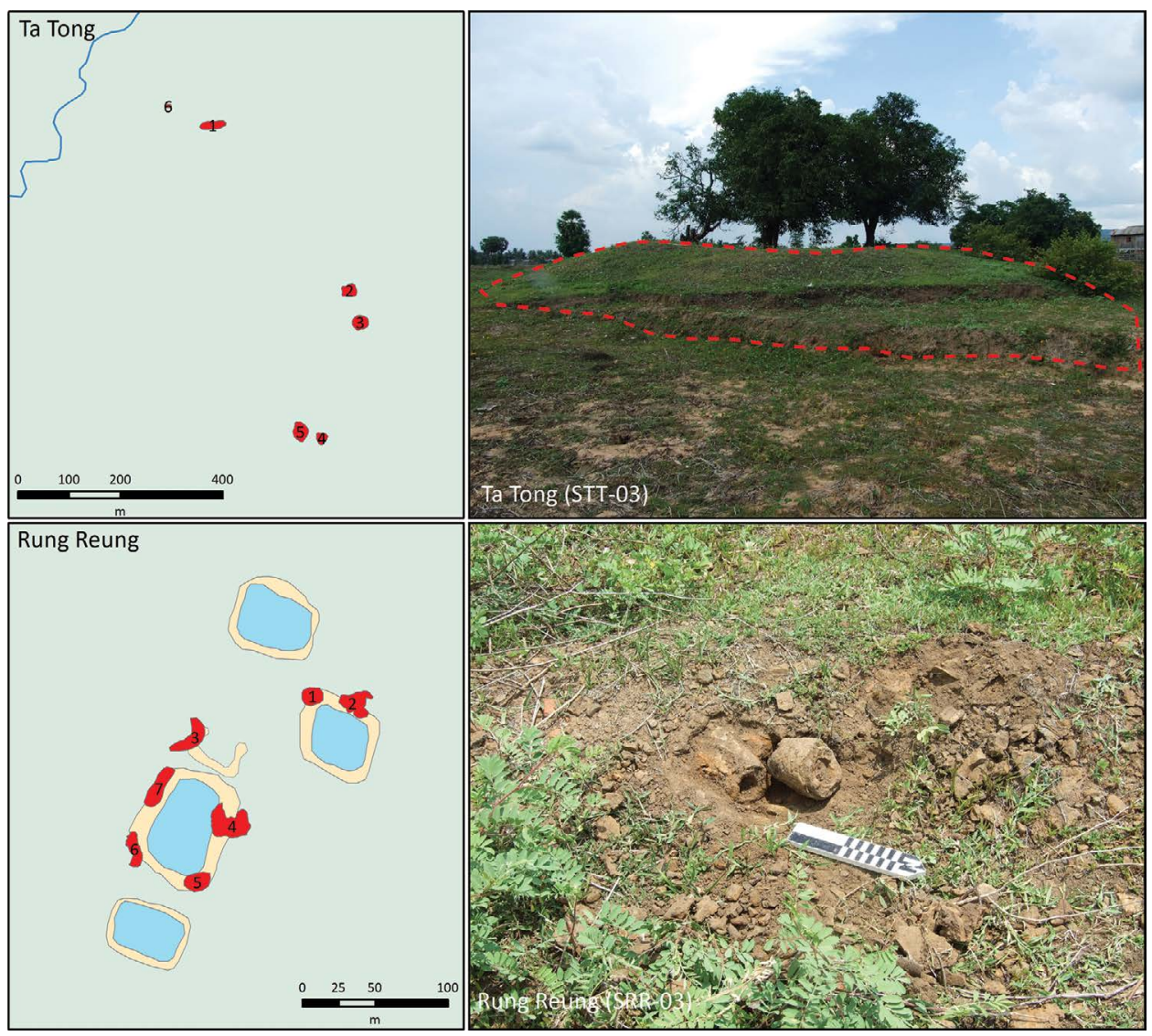

Fig. 8. East Phnom Dek: distribution of slag concentrations at Ta Tong and Rung Reung. Images show mound cut at the base by rice-field clearance at Ta Tong (STT-08) and a pair of broad-gauge tuyères at Rung Reung (SRR-03). 


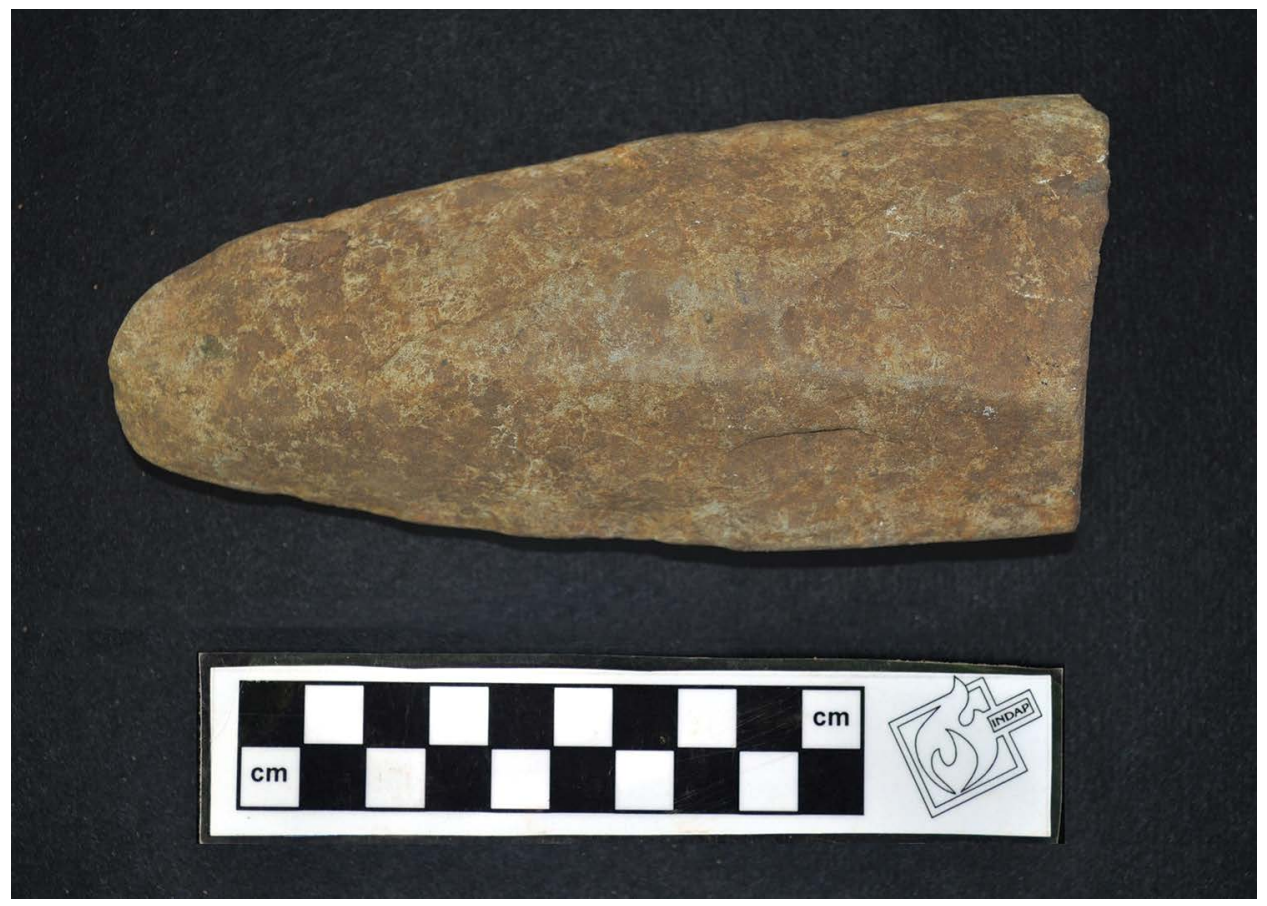

Fig. 9. Stone tool recovered from Ta Tong (STT-01).

mounds is relatively small $(0.5-1.3 \mathrm{~m}$ in height) and has an abundance of tuyères that appear to fit the medium-gauge type. One unique find on the surface of STT-01 was a stone in the form of a hammer or adze (Fig. 9). If this tool is associated with the metallurgical site, it could have been used for preparing ore or removing excess slag after the bloom was extracted.

Rung Reung is a dense cluster of low mounds situated around several small trapeang. The mounds show the presence of two different production systems (Fig. 8). Mound SRR-04 has medium-gauge tuyères and dark slag on the top of the bank, but a small looters' pit cut into the internal face contains the greenish-yellow type found at Boeng west. This slag is also found at mound SRR-03 in association with two sets of broad-gauge tuyères. While the mound size at Rung Reung does not suggest long-term use, spatial and vertical evidence are strongly indicative of a transition between different technological systems.

Phum Sanlong includes a series of three low mounds $(0.5-1.5 \mathrm{~m}$ high) and a scatter of metallurgical debris. This is the only concentration in the east region that exclusively produced thin-gauge tuyères.

\section{SURVEY RESULTS}

Data and material (morphology, tuyères, mineral, and slag) collected from the surface surveys enable us to generate some basic patterns for the technological systems within the Phnom Dek region. The following discussion evaluates slag concentration forms, 
tuyère dimensions, slag morphology, and the chemistry and results of radiocarbon analysis of in-slag charcoal.

\section{Slag Concentrations}

Table 1 summarizes the number, size, and type of concentrations (Cn) at each site. The greatest numbers of individual heaps are found at Boeng east, Chhay, and Tonle Bak. The highest and largest mounds are at Boeng west, with the average footprint $\left(2525 \mathrm{~m}^{2}\right)$ of mounds there nearly four times greater than at any other site. A second size class of concentrations (averaging approximately $700 \mathrm{~m}^{2}$ ) is also evident at Boeng east, Tonle Bak, Prei Russei, and Chhay. The smallest concentrations (at Phum Sanlong and Trapeang Sanlong) have total footprints less than $100 \mathrm{~m}^{2}$.

Although assessing profiles of some heaps was hindered by vegetation coverage that obscured details such as slope orientation or presence of ridges, we found that the most common concentration profiles were simple mounds $(70 \%)$, followed by flat scatters and irregular mounds. Irregular mounds are only found at four sites (Sre Po, Chhay, Boeng east, and Ta Tong). Ridged mounds, one of the most distinctive profiles, are limited to Tonle Bak. Tonle Bak stands out for containing four of the five profile types (flat, simple, raised, ridged), while Boeng east has three. The majority of sites typically have only one or two profiles. Basic morphology therefore provides a parameter for visualizing the density of production activities and potentially informing about furnace sizes.

\section{Tuyères}

The visibility of tuyères on the surfaces of mounds varied dramatically. This is likely related to furnace composition, method of bloom extraction, or long-term erosion caused by heavy monsoon rains. Field identification suggested the presence of three distinct sizes of tuyères: thin, medium, and broad gauge (Fig. 10). To test this initial assessment, a total of 267 tuyères were collected from 40 individual slag concentrations (Table 2). Measurements were obtained from 256 samples providing data on bore width, wall thickness, and length. Comparison of mean bore size to mean wall thickness across the assemblage corroborates the presence of three distinct forms (Fig. 11). This result also corresponds with three different signatures identified from previous studies of tuyères from Tonle Bak (TBAD-1), Preah Khan of Kompong Svay, and Sanlong Jaya (Pryce, Hendrickson, et al. 2014).

In terms of distribution, the majority of sites are characterized by one type of tuyère. Two different patterns were also evident within the PD East and PD South regions. The first is the presence of multiple tuyères on a single concentration. Two mounds at Boeng East (SBO-02, SBO-03) had thin- and medium-gauge examples on their surface. The second pattern shows variation across the site. In this case, individual mounds had only one tuyère form but the type varied between concentrations. This was noted at three sites: Rung Reung (medium and broad), Chhay (thin and medium), and Ta Tong (medium and thin). Based on previous chronological associations of the medium type with Angkor and post-Angkor and the thin type with late to post-Angkor (or Kuay), it appears that several sites experienced multiple phases of usage. Radiocarbon dating of sites with broad gauge tuyères at Rung Reung and Boeng is needed to determine whether there is a significant temporal difference between medium- and broad-gauge production. 


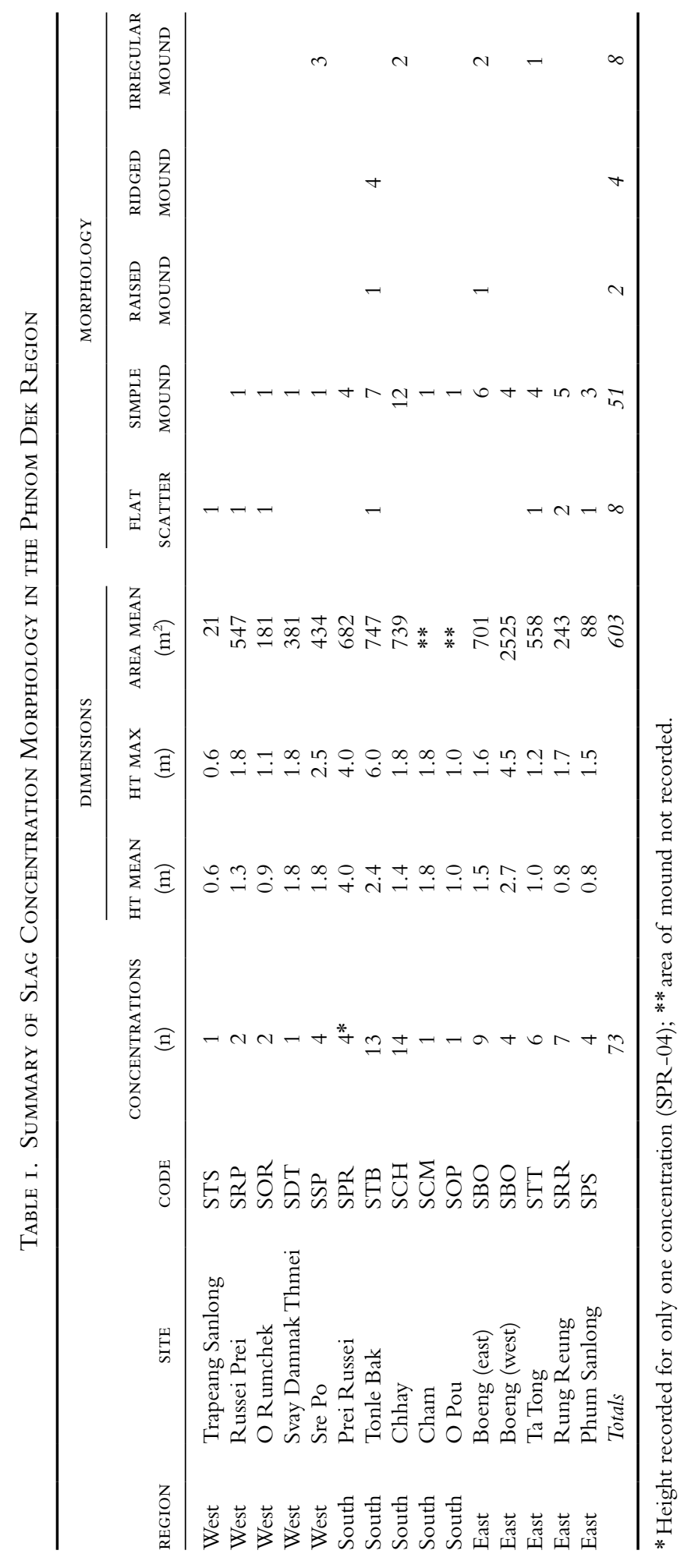



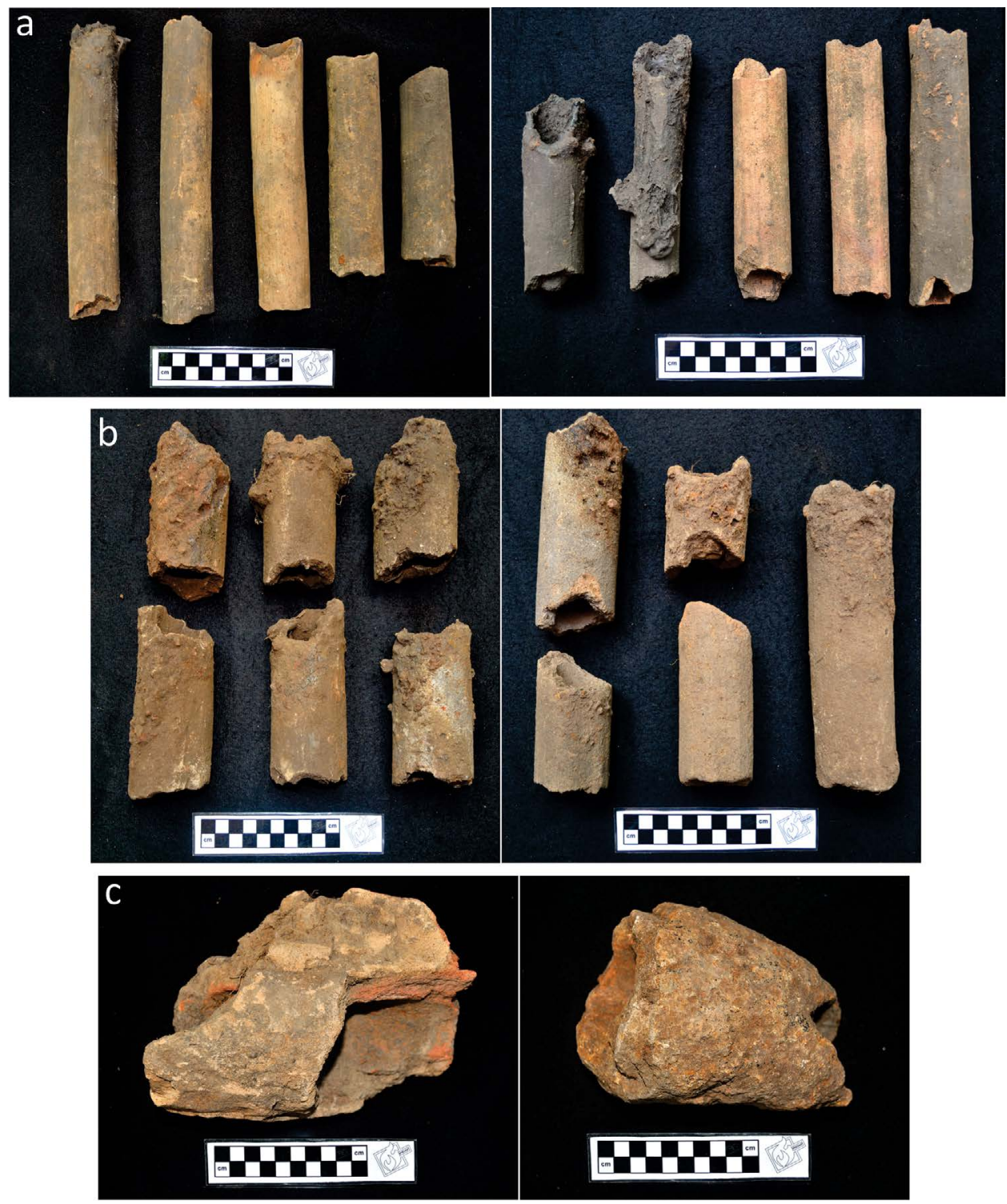

Fig. 10. Tuyère forms identified in the Phnom Dek region: a) thin gauge from Sre Po (SSP-02) and Chhay (SCH-01); b) medium gauge from Tonle Bak (STB-05) and Chhay (SCH-04); c) broad gauge from Rung Reung (SRR-03)

\section{Minerals}

Small quantities of unprocessed mineral or gangue minerals were noted at the surface of many sites. Combined with the massive volumes of slag and substantial quantities of tuyères, it is clear that the majority of sites around Phnom Dek were primarily focused on smelting rather than smithing iron. 


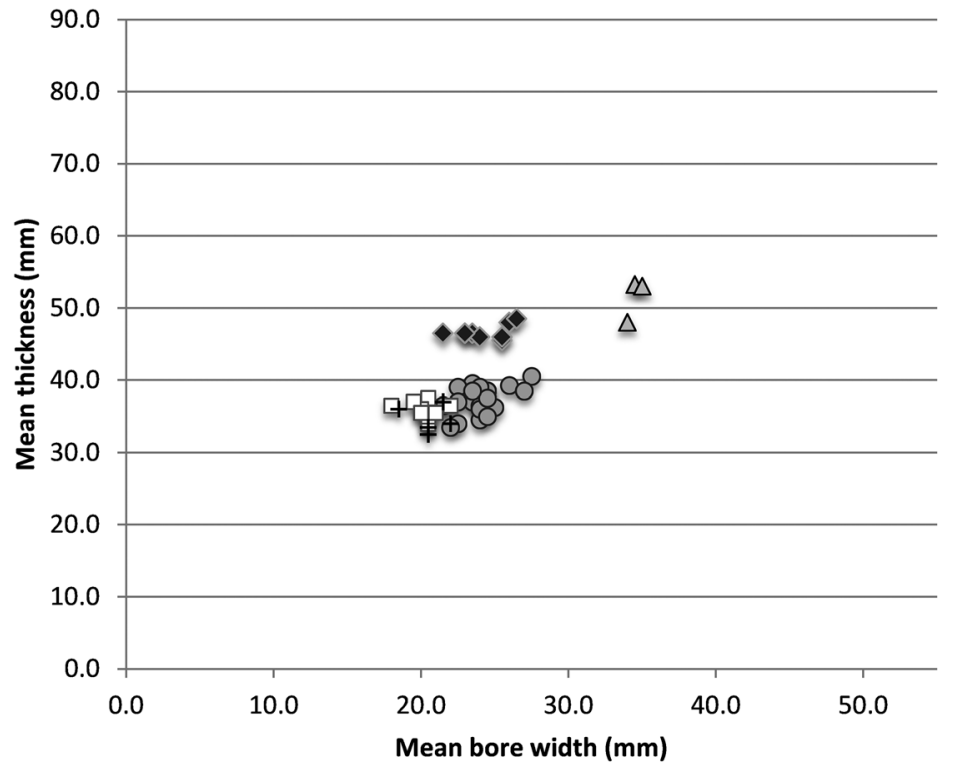

\section{Phnom Dek \\ West}

O Sre Po

$\square$ O Rumchek

$\triangle$ Russei Prei

- Trapeang Sanlong

+ Svay Damnak Thmei

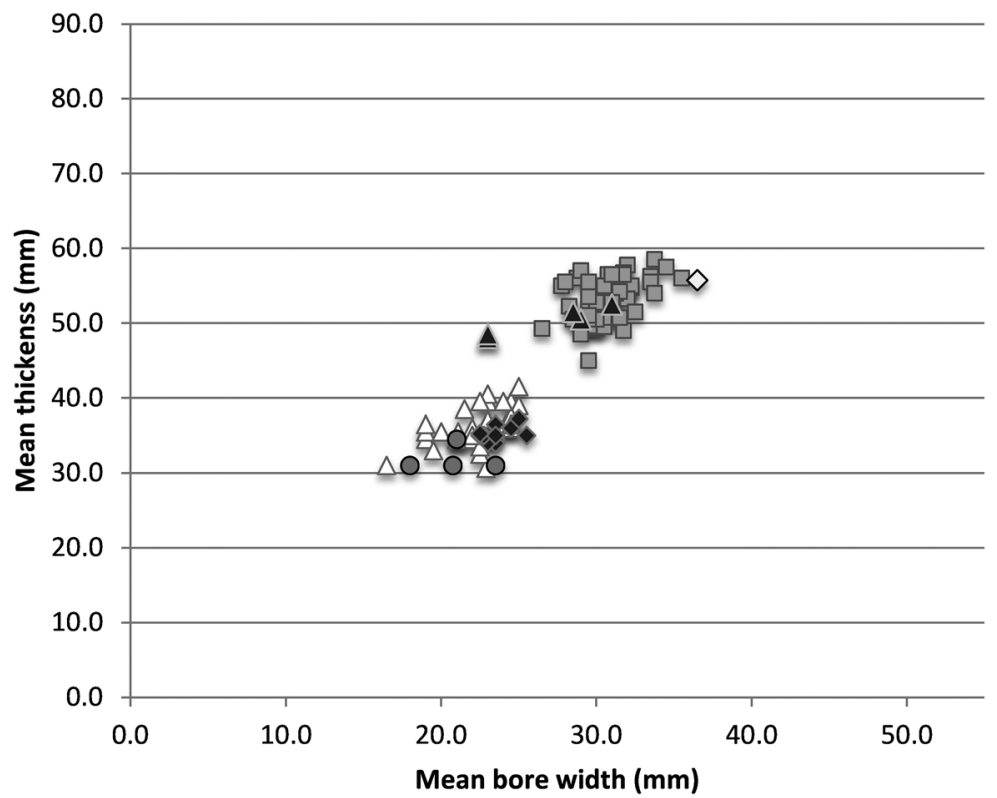

Phnom Dek South

$\square$ Tonle Bak

$\triangle$ Chhay

$\Delta$ Chhay-04

$\bullet$ Cham

OO Pou

$\diamond$ Prei Russei

Fig. 11. Comparison of mean bore width and mean tuyère diameters from the three survey zones and all zones combined: Phnom Dek West (top); Phnom Dek South (bottom).

\section{Slag Morphology}

Tap slag was the predominant type of slag found during the surveys. Tap slag forms as the liquid waste material separates from the iron bloom and cools into distinct flows that come out from the furnace base during the primary reduction process. This activity serves to extend the life of the smelt by preventing blockage of airflow through 


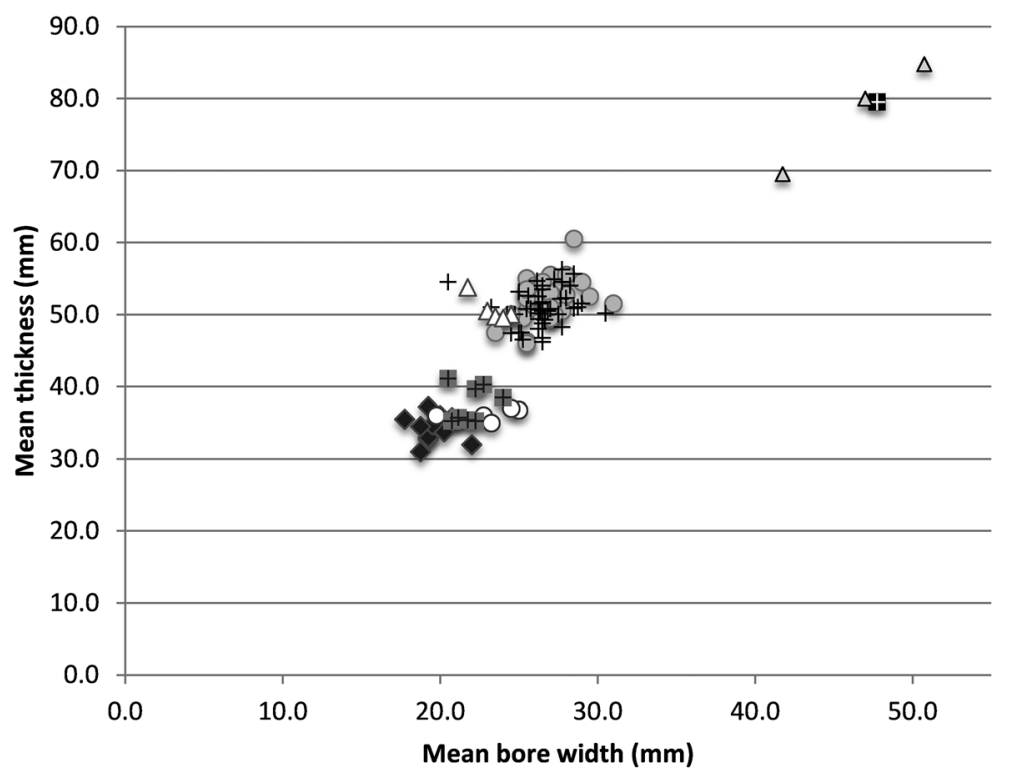

\section{Phnom Dek East}

- Phum Sanlong

Ta Tong

OTa Tong-04

+ Boeng East

\# Boeng East-02

\#Boeng West-11

$\triangle$ Rung Reung

$\triangle$ Rung Reung-03

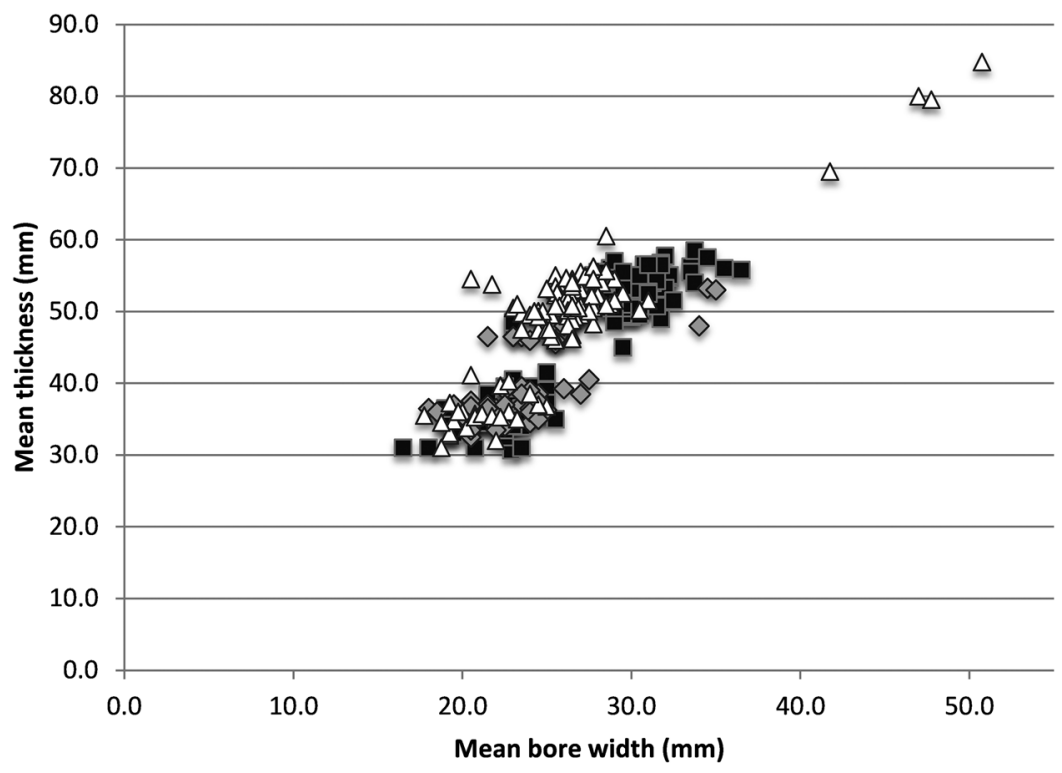

Phnom Dek

Region

a PD South

$\diamond$ PD West

$\triangle \mathrm{PD}$ East

Fig. 11 (continued). Comparison of mean bore width and mean tuyère diameters from the three survey zones and all zones combined: Phnom Dek East (top); Phnom Dek region (bottom).

the tuyères. No samples of secondary production slags such as plano-convex or smithing hearth bottoms were collected during the survey, perhaps due to their smaller size. Recognition of other smithing slags or hammerscale as part of the secondary manufacturing process requires more intensive study not possible during an intensive landscape survey.

Three main types of tap slag are identifiable in the Phnom Dek region. The first is black with a smooth, shiny surface and ranges in size from small fragments to broad, 
Table 2. Summary of Tuyère Forms Recorded from Slag Concentrations (Cn) in the PhNom Dek Region

\begin{tabular}{|c|c|c|c|c|c|}
\hline PD REGION & SITE & SITE CODE & TUYÈRES (n) & $\begin{array}{l}\text { Cn SAMPLED } \\
\text { (TOTAL Cn) }\end{array}$ & TYPE \\
\hline West & O Rumchek & SOR & 10 & $1(2)$ & Thin \\
\hline West & Russei Prei & SRP & 3 & $1(2)$ & Medium \\
\hline West & Sre Po & SSP & 21 & $4(4)$ & Thin \\
\hline West & Svay Damnak Thmei & SDT & 5 & $1(1)$ & Thin \\
\hline West & Trapeang Sanlong & STS & 9 & $1(1)$ & Medium \\
\hline South & Cham & SCM & 12 & $1(1)$ & Thin \\
\hline South & Chhay* & $\mathrm{SCH}$ & 29 & $5(14)$ & Thin \\
\hline South & Chhay (SCH-04)* & $\mathrm{SCH}$ & 5 & $1(14)$ & Medium \\
\hline South & O Pou & SOP & 4 & $1(1)$ & Thin \\
\hline South & Prei Russei & SPR & 1 & $1(4)$ & Medium \\
\hline South & Tonle Bak & STB & 48 & $7(12)$ & Medium \\
\hline East & Phum Sanlong & SPS & 12 & $2(4)$ & Thin \\
\hline East & Rung Reung* & SRR & 5 & $2(7)$ & Medium \\
\hline East & Rung Reung (SRR-03)* & SRR & 3 & $1(7)$ & Broad \\
\hline East & Ta Tong* & STT & 30 & $3(6)$ & Medium \\
\hline East & Ta Tong (STT-04)* & STT & 6 & $1(6)$ & Thin \\
\hline East & Boeng east** & $\mathrm{SBO}$ & 44 & $7(9)$ & Medium \\
\hline East & Boeng east (SBO-2, SBO-3)** & $\mathrm{SBO}$ & 8 & $2(9)$ & Thin \\
\hline East & Boeng west & $\mathrm{SBO}$ & 1 & $1(3)$ & Broad \\
\hline
\end{tabular}

*Indicates multiple types of tuyères found at the site; **indicates multiple types found on an individual mound.

flat fans (Fig. 12a). The second are large masses of slag composed of different layers, referred to as slag cakes (Fig. 12b). Slag cakes were visible at many sites, with some examples weigh upwards of $80 \mathrm{~kg}$. The typical flowing pattern characteristic of the top of each layer, the empty spaces often observed between layers (along with the absence of footprints of charge pieces), and the multiple layers in each cake lead us to think that each cake formed from several tapping episodes during a single smelt or perhaps multiple uses of a furnace. Cutting the slag cakes revealed the presence of charcoal fragments (used for AMS dating, see below) from the firing process as well as partially formed iron within some layers. This suggests that the cakes formed close to or perhaps inside furnaces. Excavation of a complete or semi-intact furnace is required to confirm how these slag cakes formed.

The final type of tap slag has a greenish-yellow surface color and is restricted to Boeng west and two mounds at Rung Reung (SRR-03, SRR-06). In addition to its unique color, the slag often shows linear striations on one side (Fig. 12c). This trait appears to be caused by contact with the surface of a plant or other materials either within the furnace or as the slag flowed out. Mounds with this greenish-yellow slag are covered with small, fragmentary pieces of it and lack the large, surface tap cakes found at other sites. These slag characteristics alone are evidence of the presence of a third technology in the Phnom Dek region.

\section{Slag Chemistry}

Fragments of tap slag collected from the field survey were analyzed to establish baseline chemical compositions. The elemental signature or smelting recipe of a given 

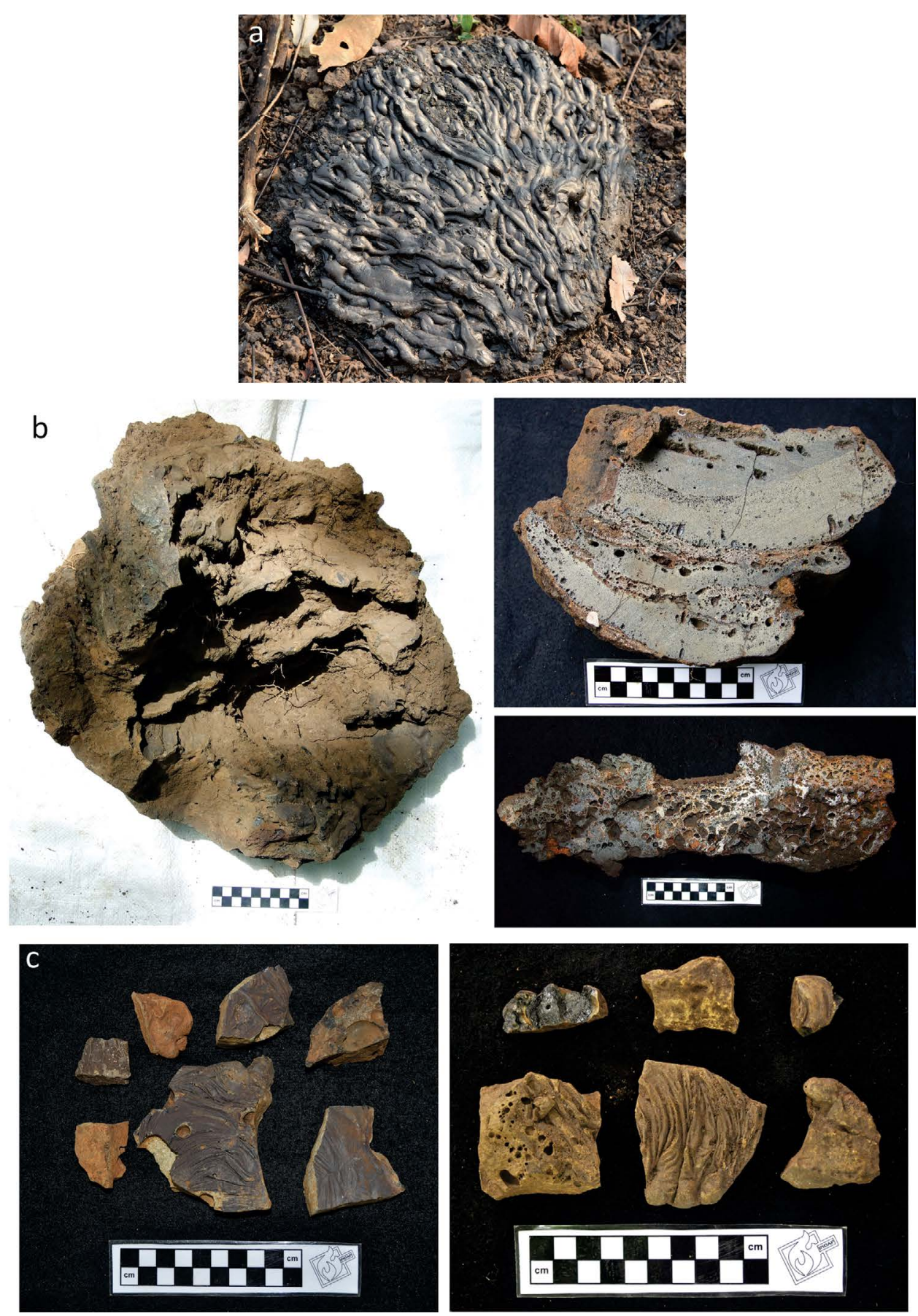

Fig. 12. Tap slags identified in the Phnom Dek region: a) black, smooth slags; b) large slag cakes (left) from Russei Prei (SRP-01 SSC-1); (right upper) cut section of cake from Tonle Bak (STB-02 SSC-1); (right lower) cut section of cake from Chhay (SCH-01 SSC-5); c) greenish-yellow slag fragments (left) from $\mathrm{SBO}-12$; (right) fragments from $\mathrm{SBO}-11$. 
reduction system is determined by what ingredients (i.e., ore, refractory clay from the furnace wall or tuyères, and fuel) are combined during the production process (Charlton 2009; Desaulty et al. 2009; Dillmann and L'Héritier 2007; Leroy et al. 2012; Ploquin et al. 1996). The goal here is to begin the process of characterizing smelting traditions and identify regional variability in ore use across the Phnom Dek region.

Selected slag samples were crushed into powder, sieved at $80 \mu \mathrm{m}$, and examined using bulk methods of analysis to generate the average elemental composition of the slag. Bulk trace elemental composition was determined by ICP-AES (inductively coupled plasma atomic emission spectroscopy) for the quantification of the major elements and ICP-MS (mass spectrometry) for minor and trace elements at the Service d'Analyse des Roches et Minéraux, Centre de Recherches Pétrographiques et Géochimiques (SARM-CRPG-CNRS-Nancy, France) (Carignan et al. 2001). The compositional data of tap slags from multiple sites were then evaluated using multivariate statistics to plot overall slag chemistry (Charlton et al. 2010; Leroy et al. 2014). Compounds that are not reduced (non-reduced compounds or NRC) during the smelting process are included in this study. The NRC involved here include trace, minor, and major elements: $\mathrm{Mg}, \mathrm{Al}, \mathrm{Si}, \mathrm{P}, \mathrm{K}, \mathrm{Ca}, \mathrm{Ti}, \mathrm{V}, \mathrm{Mn}, \mathrm{Y}, \mathrm{Nb}, \mathrm{Cs}, \mathrm{La}, \mathrm{Ce}, \mathrm{Nd}$, $\mathrm{Pr}, \mathrm{Sm}, \mathrm{Eu}, \mathrm{Gd}, \mathrm{Yb}, \mathrm{Hf}, \mathrm{Th}, \mathrm{Tb}$, and U. (Lithophilic elements such as $\mathrm{Na}$, Cs, and Sc are often below the detection limit, so were removed from this set.) Among these elements, a subset (mainly Y, Nb, La, Ce, Pr, Nd, Gd, Sm, Eu, Tb, Yb, Hf, Th, and U) are not significantly affected during the smelting process and retain a comparable concentration ratio from ore sources to slag samples. This set can be more specifically used to define an elemental signature of a given ore extraction area.

The multivariate analysis of the elemental signature of tap slag is based on a scale invariant representation of the elements' concentrations. The log-ratio transformation is used here to delete the dilution effect that occurs during the iron-making process, which is shown to be of particular interest in sourcing investigation (Aitchison et al. 2002; Baxter and Freestone 2006; Charlton et al. 2012; Leroy et al. 2012). This allows comparison of oxide ratios that can be used to define the chemical signatures of each sample. We therefore use the log 10 of each elemental (E) amount that is divided by the geometrical mean of the $\log 10$ of the best-measured elements (Leroy et al. 2012). We distinguish two sets of variables: the first consisting of trace elements and the second involving major and minor elements (Disser et al. 2016).

Smelting slags created by different smelting recipes tend to form clusters in the multivariate space with the relative positions indicating compositional differences in ore, clay, or fuel ash chemistry (Charlton et al. 2010). Evaluation of bulk composition helps us investigate variations in chemical patterns or signatures, which then become important markers of technological parameters of diversity (i.e., differences in or between smelting cycles; use of multiple production recipes). Discussing such variations requires a statistically representative number of specimens to be able to account for sampling errors as well as heterogeneity within each chemical signature (Charlton et al. 2010; Leroy et al. 2014). As the survey data set is currently insufficient to make meaningful technological interpretations, the focus instead is on identifying initial compositional patterns related to resource selection for the smelting process.

Due to the low number of samples for some sites (e.g., five for Russei Prei and one for Sre Pro), we assigned smelting slags to regional groups (e.g., PD West, PD South). Due to the large distances separating the sites in PD East, they were further divided 

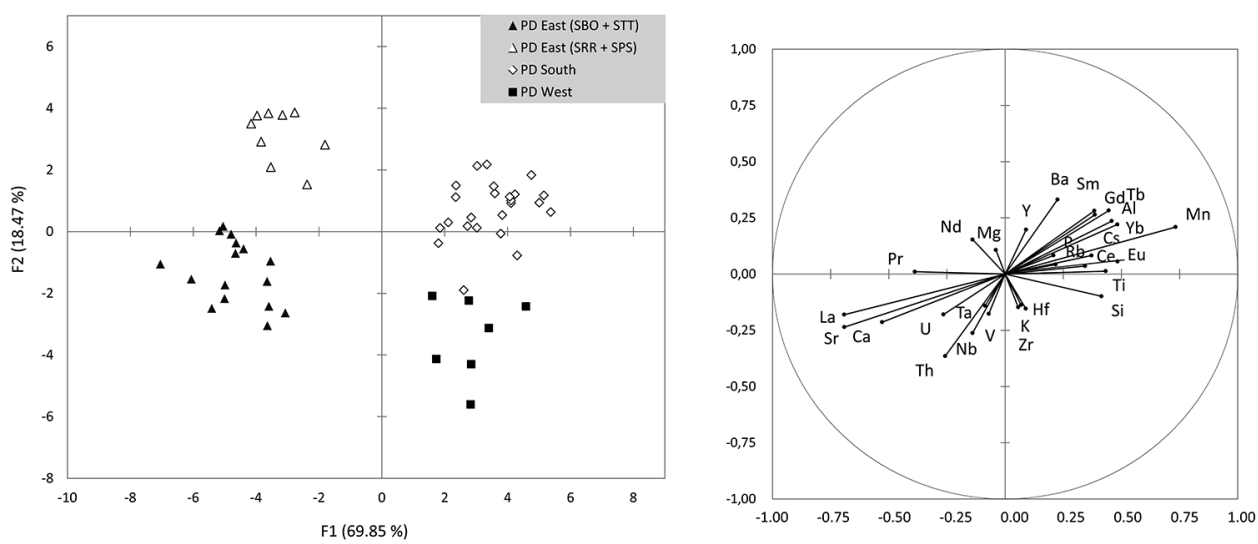

Fig. 13. Plot of the scores based on the first two components from the LDA of the variables $X_{E}$ (elemental logratio) of the slag samples from the 2013 surveyed sites (left) and plot based on the coefficients of the leading two components (right).

into East PD (SBO + STT) and East PD (SRR + SPS). A linear discriminant analysis (LDA) was applied to the defined groups (Fig. 13). A conservative interpretation of the LDA allows us to divide slag chemistries into at least two main groups. The PD East tap slags have a high correlation with $\mathrm{La}$, Sr, and $\mathrm{Ca}$ subsets, while the PD West and PD South slag samples are distinguished by higher contributions of $\mathrm{Mn}$, for example (especially the PD South samples). The difference detected in oxide ratios is expected to be displayed by the concentrations themselves. Tap slag from PD East sites can therefore be expected to be relatively richer in oxides of $\mathrm{La}$, Sr, and $\mathrm{Ca}$ and poorer in $\mathrm{MnO}$ than examples collected from sites to the west and south (Fig. 14).

The two main clusters of compositional differences represent at least two different smelting recipes whose relative positions indicate compositional differences in ore, clay, and fuel ash chemistry, as well as variation in furnace design and operation. Following the general model of parent material contributions to slag chemistry (Charlton et al. 2010; Crew 2000; Serneels 1993b), the positive correlations in elements such as $\mathrm{Sr}$ and $\mathrm{Ca}$ would suggest at first that groups containing larger amounts of these oxides were formed from higher relative contributions of fuel ash or the use of a charcoal with higher ash content. On the other hand, the difference in $\mathrm{MnO}$ between both groups supports the finding of variation in utilized ores. This interpretation is also based on the differences noted in specific trace elements that reflect the nature of the ore resource, such as the difference and positive correlation between $\mathrm{Sm}$ and $\mathrm{Eu}$. Thus, the formation of two main clusters may be attributed primarily to variation in slag chemistry due to ore sources, with minor contributions from fuel ash.

The results of this preliminary investigation indicate that ores used in the PD East region were sourced from locations other than those used in PD West and PD South. Working from the assumption that the PD South sites relied on ore from nearby Phnom Dek and that there is no significant variation in the chemistry of ore from Phnom Dek, we suggest that sites east of Phnom Dek obtained ore from other locations. Confirmation of this interpretation will require the identification of other potential ore resources in the region as well as characterization of the ores. Assessing 


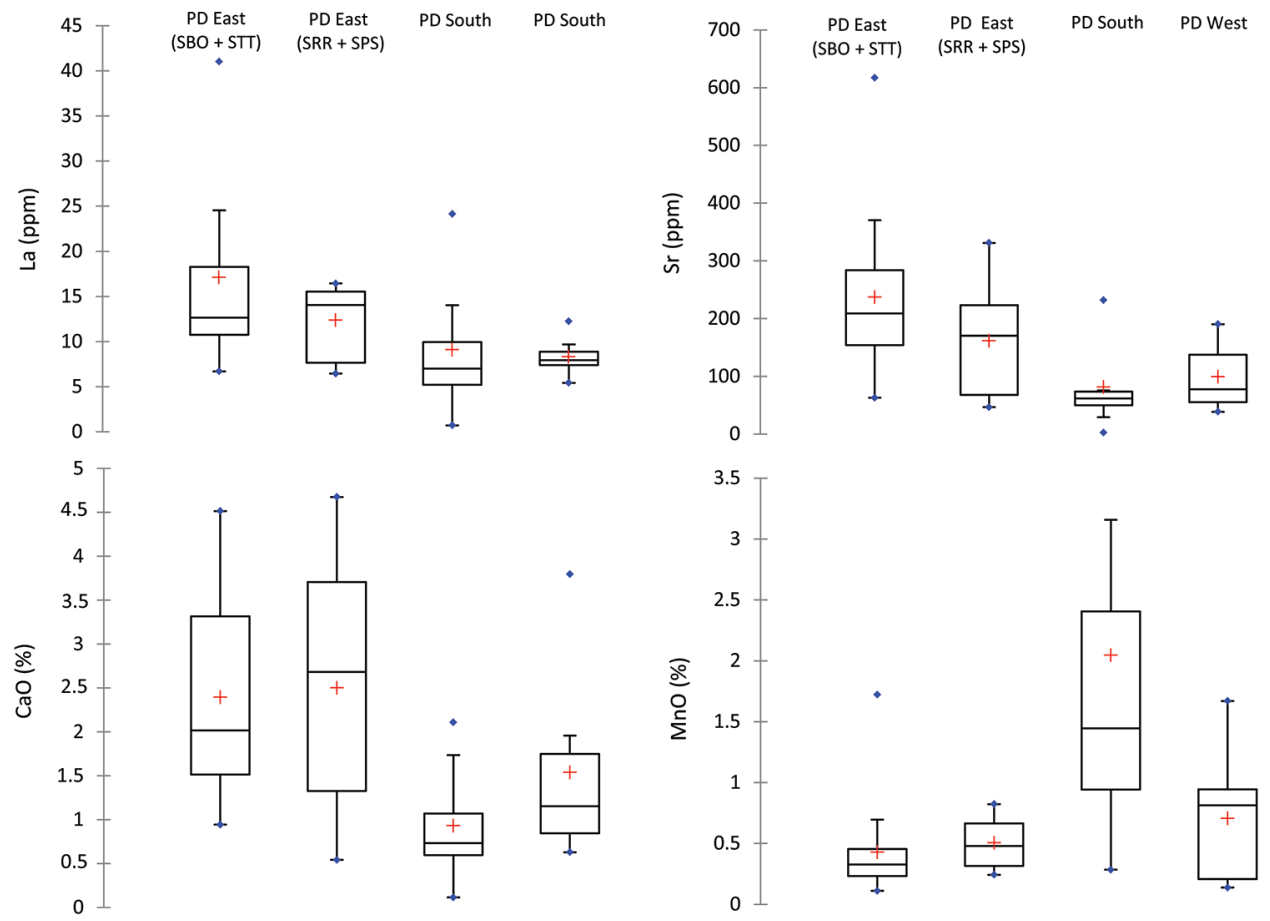

Fig. 14. Distribution of contents of elements in tap slag samples from 2013 surveyed sites: La (ppm) (top left); $\mathrm{Sr}$ (ppm) (top right); $\mathrm{CaO}$ (\%) (bottom left); $\mathrm{MnO}$ (\%) (bottom right).

variability and differences in iron-production systems requires interpreting the chemistry of a more representative set of spatiotemporally distributed tap slag.

\section{IN-SLAG RADIOCARBON DATES}

Large tap slag cakes were collected from specific concentrations to obtain in-slag charcoal for AMS radiocarbon dating (see protocol developed in Hendrickson et al. 2013). Charcoal samples derived from slag cakes found on top of the mounds or trapped inside the bore of tuyères were dated at the STAR AMS facility at ANSTO (Fink et al. 2004; Hua et al. 2001). Selection of slag cakes was restricted to the top of each feature as slag cakes are more likely to be in situ at the top than those at the base. Dates obtained from these cakes are best viewed as terminal smelting events at each location. Eighteen radiocarbon dates were obtained from thirteen different slag concentrations (Table 3).

Previous tests of in-slag charcoal from these contexts have revealed consistent results for estimating a terminal smelting date for a given mound (Hendrickson et al. 2013). To test the validity of the 2013 survey, multiple samples were taken from four different concentrations. Different slag cakes from three concentrations within Tonle Bak (OZQ832 and OZQ833 from STB-02; OZQ961 from STB-05; OZQ836 and OZQ962 from STB-07) produced comparable Angkor-type results within and between individual mounds. The concentration cut in half by road development at Boeng (SBO-09) allowed us to sample two different stratigraphic levels below the 


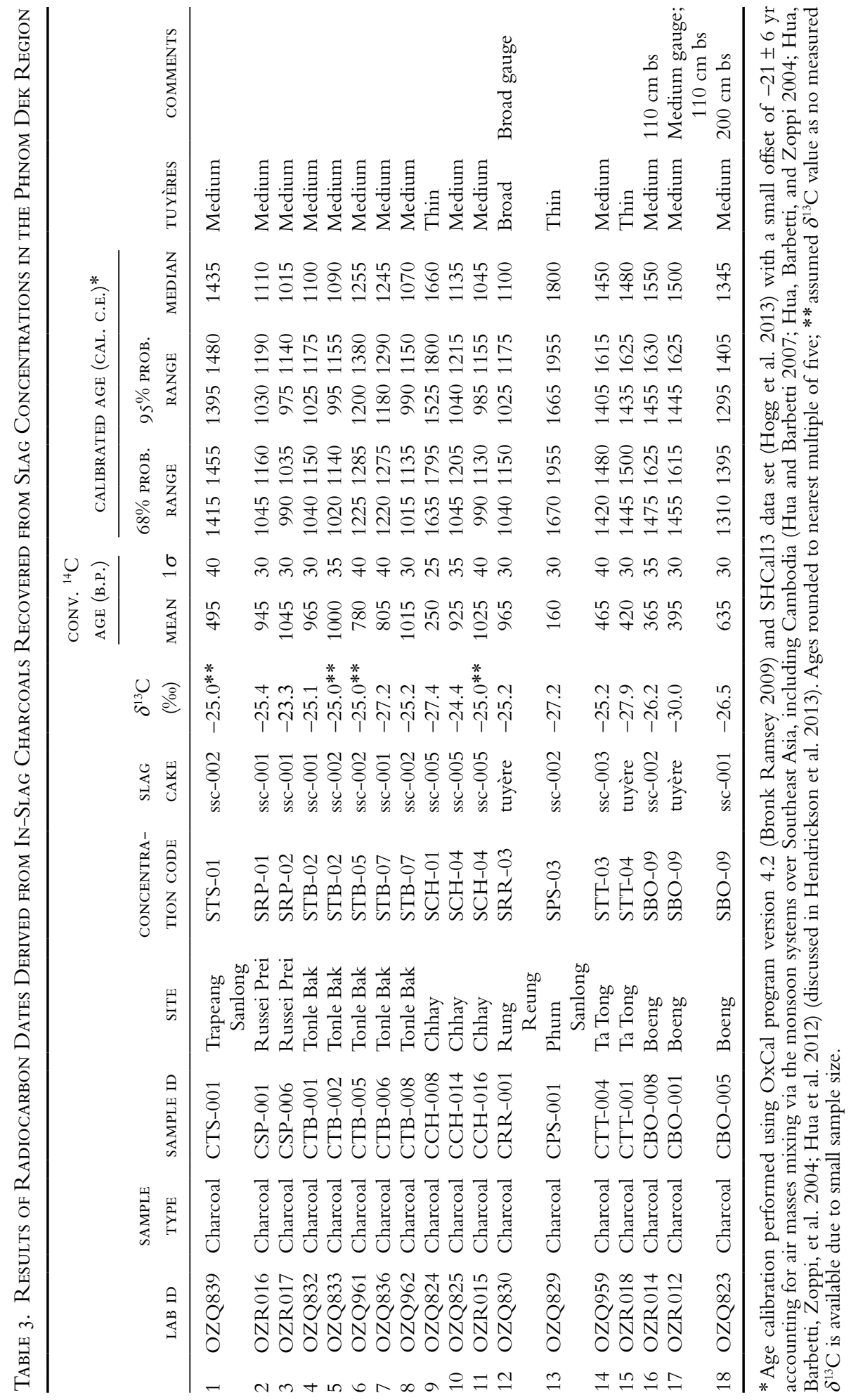


surface of the mound. A slag cake was obtained at $110 \mathrm{~cm}$ and a tuyère at $160 \mathrm{~cm}$ in the upper level; another slag cake was obtained from the lower level at $200 \mathrm{~cm}$. Both upper samples (OZR014, OZR015) fit within a range attributed to the early postAngkor period, while the lower sample (OZQ823) is associated with late Angkor.

Radiocarbon dating of charcoal obtained from inside a tuyère at Ta Tong mound 4 (sample CTT-001 OZR018) raised the only chronological issue. While analysis of this sample suggests it was produced in the late Angkor to post-Angkor era, the thin gauge of the tuyère is aligned with more recent production styles. The 2-sigma date range suggests that an early seventeenth-century date could match the oldest date from Phum Sanlong (sample CPS-001 OZR829). Without more dates from thingauge sites, it is impossible to determine whether this is a case of contamination or this technological system was active during the early post-Angkor period.

Previous chronological studies of sites around Phnom Dek demonstrated a smelting history anchored between the ninth and twentieth centuries (Pryce, Hendrickson, et al. 2014). Our new set of radiocarbon dates enable us to partially fill in this vast temporal range. By correlating these new dates with tuyère forms, we now identify three phases or traditions of iron smelting (Table 4). The first phase is associated with the expansion of the Khmer Empire between the tenth and thirteenth centuries (represented at Tonle Bak, Rung Reung, Prei Russei, and Chhay). The second phase corresponds to the collapse of Angkor and initial stages of the middle post-Angkor period between the late fourteenth and early sixteenth centuries (at Boeng, Ta Tong, and Trapeang Sanlong). The final phase relates to the later post-Angkor period and the activities of the Kuay until the modern era.

\section{THE PHNOM DEK IRON LANDSCAPE}

A holistic view of the metallurgical evidence is necessary to begin comprehending the scale, technological history, and cultural significance of the vast landscape around Phnom Dek. Industrial activities spanning distances over $40 \mathrm{~km}$ are clearly evident to the west, south, and east of the mountain. An estimate of how much iron was produced within this area is complicated by variability in mound size and density of industrial material. However, a basic estimation technique (area $\times$ height) used in other regions indicates there is approximately $105,000 \mathrm{~m}^{3}$ of material around Phnom Dek. To get a sense of how this compares with other premodern states, surveys of Romano-British period sites (first century B.C. to fifth century A.D.) in the Weald of Southeast England estimate iron production material at $148,000 \mathrm{~m}^{3}$ (Hodgkinson $2008: 31)$. It is important to realize that mound size does not correlate directly to output. A more realistic estimation requires conversion from area to mass $(\sim 1600 \mathrm{~kg}$ per $\mathrm{m}^{3}$ [using coarse dry sand as a proxy]) and the average percentage of slag by mass $(30 \%)$ as determined from previous excavations (Pryce, Hendrickson, et al. 2014). Using this revised formula, we approximate potential total mass of slag within the Phnom Dek area at over 50,000 metric tons. While the actual iron output requires a much more informed calculation, this figure demonstrates the significance of Phnom Dek as a major focal point of Cambodian production. It was certainly used as extensively as other major iron ore sources worldwide.

Taking a technological perspective, we confirm the presence of at least three different smelting systems that are generally identifiable through tuyère gauge (medium, broad, thin). Medium-gauge sites are characterized by numerous tuyères in association with large, black slag cakes. This system is the most common across the Phnom 


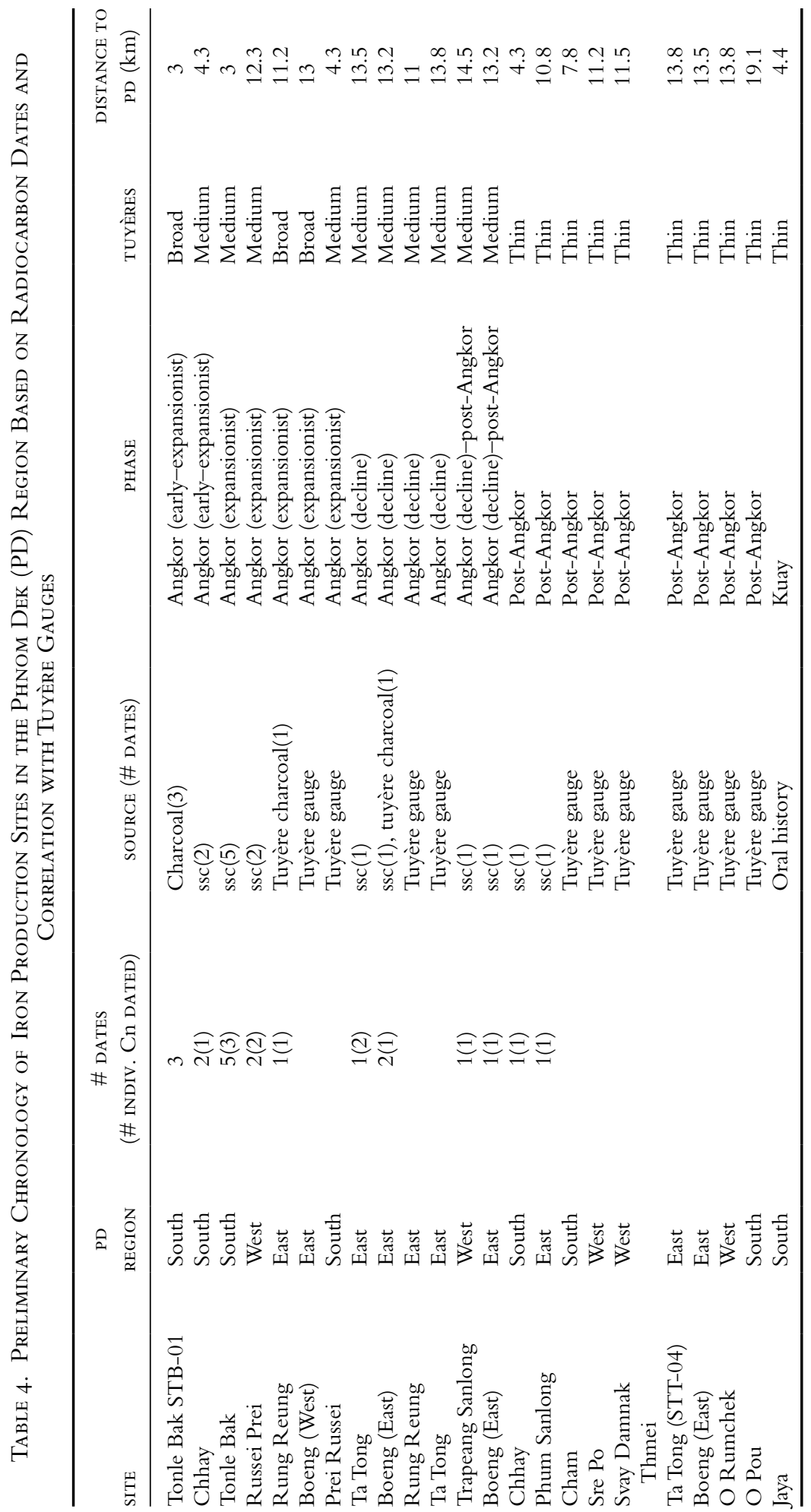


Dek region and is the only type found farther west at Preah Khan of Kompong Svay (Hendrickson et al. 2013) and Khvao (Im 2011). These sites have the broadest time depth (eleventh to sixteenth centuries) with clusters in both Angkor and early postAngkor periods.

Broad-gauge sites are defined by mounds with densely packed greenish-yellow tap slag and no large slag cakes. Tuyères are extremely rare and have only been found near the base of these mounds, probably because of recent looting activities. These sites are limited to the area east of Phnom Dek and are tentatively associated with the Angkor period. The relationship of these sites to the broad tuyère system identified at Tonle Bak (STB-01) south of Phnom Dek is currently unclear. Excavation at the single mound at Tonle Bak similarly recovered few tuyères. The slag is black and sparsely distributed throughout the mound (Pryce, Hendrickson, et al. 2014). Tonle Bak is firmly connected to early Angkor. Further investigation is necessary to determine whether the single mound at Tonle Bak with broad tuyères represents a unique local technology or a variant of the PD East system.

The medium- and broad-gauge systems produced the largest known slag concentrations around Phnom Dek; all are contemporary with the Angkor period. It is therefore tempting to view these sites as a metallurgical intensification in response to or driving Khmer expansion between the eleventh and thirteenth centuries.

Thin-gauge sites are characterized by mounds with substantial quantities of tuyères and relatively small black slag cakes scattered on the surface. Like medium-gauge sites, examples of the thin-gauge system are found across the Phnom Dek region. Oral accounts strongly connect this technology to recent Kuay practices. Our new dating results support morphological continuity extending into the eighteenth century. Identification of multiple systems, particularly during the Angkor period, complicates any direct historical correlations to the Kuay tradition and the narrative that they were the only group smelting iron during the time of Angkor (Dupaigne 1987; Jacques and Lafond 2004). We must remain cautious about associating technologies with specific peoples since more than one smelting group may be attracted to the same ironrich resources. For example, ethnographic surveys in eastern India have identified the presence of multiple groups using typologically distinguishable technologies (Chattopahyay and Sengupta 2011:63-69). We lack a similar corpus of data for Cambodia, but the local naming of one of the sites south of Phnom Dek as "Cham" suggests that diverse producers, including other minorities and Khmer, could have had active smelting centers in the region.

The methodology and results presented here led us to conceptualize new questions about the vast iron landscape scattered across the Phnom Dek region. Survey alone cannot address the entire range of smelting system traits. Excavation is necessary to reveal critical factors such as the types and forms of furnaces in the region. Integration of data from intensive excavation with broad survey data would provide important details about changes in resource procurement over time. Although the current study does not provide a simple correlation between production sites and a single ore source, Phnom Dek was clearly one of several important sources in the region east of Angkor.

\section{FUTURE DIRECTIONS}

While this survey represents only a small proportion of the total corpus of metallurgy sites in the region, it is necessary to begin framing potential hypotheses and research 
perspectives that can be tested as more data and analyses are collected. Lacking detailed historical documents on iron production, we must consider the influences of resource- and culturally derived factors in generating different scales of production over time and space. Ore, clay, and fuel are critical elements in the primary reduction process. Of these resources, fuel is the most susceptible to overuse, since it is required for both ore preparation and adding charcoal to the furnace. Heavy deforestation as a result of major industrial activities also has an impact on both metallurgy and settlement in a region and can trigger dispersal of workshops across a landscape. Such dispersal sometimes requires technological adaptations to new fuel types and reliance on new ores (Schmidt 2009).

Environmental reasons are not the only explanations for industrial variation. Sutton (1985: 174) asserted that we must avoid getting entangled in pragmatic or ecological explanations for technological variability and consider idiosyncratic processes of cultural agency. Cultural factors influencing the organization and structure of smelting can include an increasing population, addition of new crops or agricultural techniques, politics, military innovations, and interactions with external groups (Sutton 1985 :178). A major change can be caused by customers from external groups demanding specific types of iron (Sutton 1985:166).

The relationship between producers and consumers around Phnom Dek must also be considered. As noted above, large-scale production sites during the Angkor period appear to be connected with the expansionist phase of the Khmer Empire. This compares nicely with changes in the scale and homogeneity of production around several major iron sources to meet increased state demands in West Africa (de Barros 2000:191-198) and Roman Britain (Clough 1985:180). Continued study of Angkorian objects will confirm whether the Khmer elite were concentrating on specific sources to get their iron. The lack of evidence for traces of occupation around the smelting sites in Phnom Dek is initially striking but is similarly noted in other regions such as the dense forested regions of the Kolhan plateau in east India (Mishra 2003:39-40) and the Roman Weald (Cleere and Crossley 1985). In the latter example, the absence of Roman occupation is because the land was producing iron for the state and was its property; therefore, direct oversight was not necessary. This raises the question of whether the Khmer state was directly involved in producing iron for itself or if it relied on a neighboring group that left a less visible archaeological footprint.

One final issue to consider has broader implications for iron production in Cambodia: Why does the earliest iron production from Phnom Dek date to the ninth century? If knowledge of smelting and iron sources was widely available, why does one of the region's major mineral deposits show no evidence of prehistoric or even pre-Angkor production? The answer most likely lies in the current paucity of archaeological data. Excavation has been quite limited. The most massive mounds such as at Tonle Bak and Boeng may well contain decades if not centuries of smelting activities. However, we must also consider that local producers may have been unable to smelt high-grade ore. As noted above, the earliest known prehistoric and historic smelting sites in the Khorat Plateau are associated with laterite and low-grade ores (Nitta 1997; Venunan 2016). Given that the Khorat and the Tonle Sap floodplain were part of the broader Khmer cultural sphere, the late appearance of smelting at Phnom Dek may represent a major technological transition during the rise of Angkor. 
The objective of this article was to expand upon initial surveys of iron production to determine the scale and chronology of industrial activities in the shadow of Phnom Dek. We have confirmed the presence of at least three different smelting traditions active over the last millennium. The scale of production appears to have fluctuated during this long time period, in particular at the massive sites dated to the Angkor period. Smelters appear to have used a range of ore sources in addition to Phnom Dek. Further surveys will hopefully identify the location of these mineral deposits in the region.

Regarding the issue of Kuay involvement in Cambodia's history, the evidence suggests some technological continuity of modern practices into the eighteenth century. However, the discovery of two different systems during the peak of the Khmer Empire indicates a much more complex metallurgical story. The question of the longevity and or involvement of the Kuay tradition is relevant to broader discussions of knowledge dispersal and innovation in South and Southeast Asia. Juleff's (2009) model of the evolution and appearance of natural updraft furnaces with multiple tuyères included the Kuay as part of a sequence that culminated with Japanese tatara furnaces. Archaeological evidence now raises a directional issue, since the Japanese system may predate the one in Cambodia. A further complication in determining the trajectory of transmission comes from historical data that show Cambodia-Japanese contact intensifying between the sixteenth and seventeenth centuries. Establishing the interrelatedness of local and foreign technologies through direct evidence is necessary to test hypotheses about interaction and dispersal. The results presented here offer a first glance at the research potential of the Phnom Dek region to address issues of Khmer history and engage in discussions of premodern iron landscapes on a global scale.

\section{ACKNOWLEDGMENTS}

This research was funded by the Campus Research Board Pilot Grant and Research Grant Support Program-Social Sciences (OSSR) from the University of Illinois at Chicago, and the French National Research Agency (IRANGKOR project ANR14-CE31-0007). Our research would not have been possible without the collaboration of the Ministry of Fine Arts and Culture in Cambodia and the efforts of our field crew. We want to thank the three anonymous reviewers who provided insightful comments on an earlier version of this article. Any errors or omissions are strictly our own.

\section{REFERENCES CITED}

Aitchison, James, Carles Barcelo-Vidal, and Vera Pawlowsky-Glahn

2002 Some comments on compositional data analysis in archaeometry, in particular the fallacies in Tangri and Wright's dismissal of logratio analysis. Archaeometry 44(2):295-304.

Baxter, Mike J., and Ian. C. Freestone

2006 Log-ratio compositional data analysis in archaeometry. Archaeometry 48(3):511-531.

Biggs, Lynn, Bérénice Bellina, Marcos Martinón-Torres, and Thomas Oliver Pryce

2013 Prehistoric iron production technologies in the Upper Thai-Malay Peninsula: Metallography and slag inclusion analyses of iron artefacts from Khao Sam Kaeo and Phu Khao Thong. Archaeological and Anthropological Sciences 5(4):311-329.

Bronk Ramsey, Christopher

2009 Bayesian analysis of radiocarbon dates. Radiocarbon $51: 337-360$. 
Carignan, Jean, Pascal Hild, Jacques Morel, and Delphine Yeghicheyan

2001 Routine analyses of trace elements in geological samples using flow injection and low pressure on-line liquid chromatography coupled to ICP-MS: Study of geochemical reference materials BR, DR-N, AN-G and GH. Geostandards Newletter 25(2-3) :187-198.

Charlton, Michael F.

2009 Identifying iron production lineages, in Pattern and Process in Cultural Evolution: 133-144, ed. Stephen Shennan. Berkeley: University of California Press.

Charlton, Michael, Eleanor Blakelock, Marcos Martinón-Torres, and Tim Young

2012 Investigating the production provenance of iron artifacts with multivariate methods. Journal of Archaeological Science 39:2280-2293.

Charlton, Michael F., Peter Crew, Thilo Rehren, and Stephen J. Shennan

2010 Explaining the evolution of ironmaking recipes: An example from northwest Wales. Journal of Anthropological Archaeology 29(3):352-367.

Chattopahyay, Pranab K., and Gautam Sengupta

2011 History of Metals in Eastern India and Bangladesh. New Delhi: Pentagon Press.

Childs, S. Terry

2000 Traditional iron working: A narrated ethnoarchaeological example, in Ancient African Metallurgy: The Sociocultural Context: 200-254, ed. Joseph O. Vogel. Oxford: AltaMira Press.

Cleere, Henry, and David Crossley

1985 The Iron Industry of the Weald. Avon: Leicester University Press.

Clough, R. E.

1985 The iron industry in the Iron Age and Romano-British period, in Furnaces and Smelting Technology: 179-188, ed. P. T. Craddock and M. J. Hughes. British Museum Occasional Paper 48. London: British Museum Research Laboratory.

Crew, Peter

2000 The influence of clay and charcoal ash on bloomery slags, in Il Ferro Nelle Alpi: Giacimenti, Miniere e Metallurgia dall' Antichità al XVI Secolo. Atti del Convegno Bienno (BS), Italy, 2-4 ottobre 1998 [Iron in the Alps: Deposits, mines and metallurgy from antiquity to the XVI century. Proceedings of the conference, Bienno, Italy, October 2-4, 1998]: 38-48, ed. C. C. Tizzoni and M. Tizzoni. Bienno: Commune di Bienno.

de Barros, Philip

1986 Bassar: A quantified, chronologically controlled, regional approach to a traditional iron production centre in West Africa. Africa: Journal of the International African Institute 56(2) : 148174.

2000 Iron metallurgy: Sociocultural context, in Ancient African Metallurgy: The Sociocultural Context: 147-198, ed. Joseph O. Vogel. Oxford: AltaMira Press.

Desaulty, Anne-Marie, Philippe Dillmann, Maxime L’Héritiera, Clarisse Mariet, Bernard Gratuze, Jean-Louis Joron, and Philippe Fluzin

2009 Does it come from the Pays de Bray? Examination of an origin hypothesis for the ferrous reinforcements used in French medieval churches using major and trace element analyses. Journal of Archaeological Science 36(10): 2445-2462.

Dillmann, Philippe, and Maxime L'Héritier

2007 Slag inclusion analyses for studying ferrous alloys employed in French medieval buildings: Supply of materials and diffusion of smelting processes. Journal of Archaeological Science 34(11): 1810-1823.

Disser, Alexandre, Philippe Dillmann, Marc Leroy, Maxime L'Héritier, Sylvain Bauvais, and Philippe Fluzin

2016 Iron supply for the building of Metz cathedral: New methodological development for provenance studies and historical considerations. Archaeometry 58:n.p. doi: 10.1111/arcm.12265.

DotTin, OLIVIER

1971 Geologie et mines du Cambodge [Geology and mines of Cambodia]. Report for the National Service of Mines, Geology and Petrol. Phnom Penh: Service National des Mines, de la Geologie et du Petrole.

DufFosé, $M$.

1934 Monographie des peuplades Kouys du Cambodge [Monograph of the Kouys people of Cambodia]. Extrême Asie 83:553-568. 
Dupaigne, Bernard

1987 Les maitres du fer et du feu: Étude de la metallurgie du fer chez les Kouy du nord du Cambodge, dans le contexte historique et ethnographie de l'ensemble Kmer [The masters of iron and fire: Study of the iron metallurgy of the Kuoy of northern Cambodia, in historical and ethnographic context of the Khmer culture]. Ph.D. diss. École des Haute Études en Sciences Sociales, Paris, France.

ELWIN, VERRIER

1942 The Agaria. Delhi: Oxford University Press.

Fink, David, Michael Hotchis, Quan Hua, Geraldine Jacobsen, Andrew M. Smith, Ugo Zoppi, David Child, Charles Mifsud, Henk van der Gaast, Alan Williams, and Megan Williams

2004 The ANTARES AMS facility at ANSTO. Nuclear Instruments and Methods in Physics Research B 223-224: 109-115.

HAALAND, RANDI

2014 The Meriotic Empire: Trade and cultural influences in an Indian Ocean context. African Archaeological Review 31:649-673.

HARMAND, JULES

1876 Voyage au Cambodge. Bulletin de la Societé de géographie de Paris (October):337-367.

HeNDrickson, Mitch

2011 A transport geographic approach on travel and communication in Angkorian Southeast Asia (ninth to fifteenth centuries A.D.). World Archaeology 43(3) : 444-457.

Hendrickson, Mitch, and Damian Evans

2015 Reimagining the City of Fire and Iron: A landscape archaeology of the Angkor-period industrial complex of Preah Khan of Kompong Svay, Cambodia (ca. 9th to 13th centuries A.D.). Journal of Field Archaeology 5 :1-21.

Hendrickson, Mitch, Quan Hua, and T. Oliver Pryce

2013 Using in-slag charcoal as an indicator of "terminal" iron production within the Angkorian period (10th-13th centuries AD) center of Preah Khan of Kompong Svay, Cambodia. Radiocarbon 55(1):31-47.

Hendrickson, Mitch, and T. Oliver Pryce

2011 Industries of Angkor Project: Iron Kuoy Project. March 2010 Field Campaign Report to the Ministry of Culture and Fine Arts. Sydney: University of Sydney.

Hodgkinson, Jeremy S.

2008 The Wealden Iron Industry. Gloucestershire: The History Press.

Hodgkinson, Jeremy S., and C. F. Tebutt

1985 A fieldwork study of the Romano-British iron industry in the Weald of southern England, in Furnaces and Smelting Technology: 159-164, ed. P. T. Craddock and M. J. Hughes. British Museum Occasional Paper 48. London: British Museum Research Laboratory.

Hogg, Alan G., Quan Hua, Paul G. Blackwell, M. Niu, C. E. Buck, Thomas P. Guilderson, T. J. Heaton, Jonathan J. Palmer, Paula J. Reimer, R. W. Reimer, C.S.M. Turney, and Susan R. H. ZimMERMAN

2013 SHCal13 Southern Hemisphere calibration, 0-50,000 cal yr BP. Radiocarbon 55:18891903.

Hua, Quan, and Michael Barbetti

2007 Influence of atmospheric circulation on regional ${ }^{14} \mathrm{CO}_{2}$ differences. Journal of Geophysical Research 112(D19): 1-13.

Hua, Quan, Michael Barbetti, Vladimir A. Levchenko, Rosane D. D’Arrigo, Brendan M. Buckley, ANd Andrew M. Smith

2012 Monsoonal influence on Southern Hemisphere ${ }^{14} \mathrm{CO}_{2}$. Geophysical Research Letters 39 (L19806) : 1-5.

Hua, Quan, Michael Barbetti, and Ugo Zoppi

2004 Radiocarbon in annual tree rings from Thailand during the prebomb period, AD 1938-1954. Radiocarbon 46:925-932.

Hua, Quan, Michael Barbetti, Ugo Zoppi, David Fink, M. Watanasak, and Geraldine E. JACOBSEN

2004 Radiocarbon in tropical tree rings during the Little Ice Age. Nuclear Instruments and Methods in Physics Research B 223-224: 489-494. 
Hua, Quan, Geraldine E. Jacobsen, Ugo Zoppi, Ewan M. Lawson, Alan A. Williams, Andrew M. SMith, AND Matthew J. MCGanN

2001 Progress in radiocarbon target preparation at the ANTARES AMS Centre. Radiocarbon $43: 275-282$.

Hudson, Bob

2006 Iron in Myanmar. Enchanting Myanmar 5:6-9.

2012 A thousand years before Bagan: Radiocarbon dates and Myanmar's ancient Pyu cities. Early Myanmar and its Global Connections Conference, Bagan, February 10-12, 2012.

Hudson, Bob, Lwin Nyein, And Win Maung

2001 The origins of Bagan: New dates and old inhabitants. Asian Perspectives 40(1): 48-74.

Humphris, Jane, and Chris Carey

2016 New methods for investigating slag heaps: Integrating geoprospection, excavation and quantitative methods at Meroe, Sudan. Journal of Archaeological Science 70:132-144.

Iles, Louise, and S. Terry Childs

2014 Ethnoarchaeological and historical methods, in Archaeometallurgy in Global Perspective: 193215, ed. Benjamin W. Roberts and Christopher P. Thornton. New York: Springer.

IM, SOKRITHY

2011 Ancient Iron Industry Project at Khvao: The Excavation Campaign 2010 and Preliminary Report. Paper presented at the 20th ICC Technical Meeting, Siem Reap, Cambodia, 8-9 June 2011.

Jacques, Claude, and Philippe Lafond

2004 L'Empire Khmer: Cités et sanctuaires Vth-XIIIth siècles [The Khmer Empire: Cities and sanctuaries 5 th to 13 th centuries]. Paris: Fayard.

JulefF, Gillian

2009 Technology and evolution: A root and branch view of Asian iron from first-millennium BC Sri Lanka to Japanese steel. World Archaeology 4:557-577.

KHIN, SOK

1988 Les Chroniques royales du Cambodge [The Royal Chronicles of Cambodia], vol. 2. Paris: EFEO.

Killick, David

2009 Cairo to Cape: The spread of metallurgy through Eastern and Southen Africa. Journal of World Prehistory $22: 399-414$.

Kramer, Carol, and Nicholas David

2001 Ethnoarchaeology in Action. Cambridge: Cambridge University Press.

Leroy, S., Serge X. Cohen, Catherine Verna, Bernard Gratuze, Florian Téreygeol, Philippe Fluzin, LoḮc Bertrand, and Philippe Dillmann

2012 The medieval iron market in Ariège France: Multidisciplinary analytical approach and multivariate analyses. Journal of Archaeological Science 39(4) :1080-1093.

Leroy, Stéphanie, Philippe Dillmann, Alexandre Disser, Maxime L'Héritier, Sylvain Bauvais, AND Philippe Fluzin

2014 Provenance et circulation des alliages ferreux [Provenance and circulation of ancient ferrous alloys], in Circulation des matériaux et des objets dans les sociétés anciennes [Circulation of materials and objects in ancient societies]: 79-108, ed. Philippe Dillmann and Ludovic Bellot-Gurlet. Paris: Editions des Archives Contemporaines.

Leroy, Stéphanie, Mitch Hendrickson, Emmanuelle Delqué-Kolic, Enrique Vega, and Philippe DillmanN

2015 First direct dating for the construction and modification of the Baphuon temple mountain in Angkor, Cambodia. PloS One 10(11): e0141052.

LÉvy, Paul

1943 Recherches prehistoriques dans la region de Mlu Prei: Accompagneés de comparaisons archélologiques et suivies d'un vocabulaire français-kuy [Prehistoric research in the Mlu Prei region: Accompanied by archaeological comparisons and followed by a French-kuy vocabulary]. Bulletin de la École française d'Extême-Orient 43. Hanoi: École française d'Extême-Orient.

LARP [Living Angkor Road Project]

2008 Living Angkor Road Project Phase II Progressive Report, October 2007-March 2008. Nakon Nayok: Chulachomklao Royal Military Academy. 
Mishra, Ashoka K.

2003 Ethno-archaeometallurgy of Iron in India. Delhi: Agam Kala Prakashan.

Mokhtar, Naizatul Akma, Mokhtar Saidin, and Jefrrey Abdullah

2011 The ancient iron smelting in SG. Batu, Bujang Valley, Kedah. Postgraduate Student Forum 21-22 January 2011, Chinese University of Hong Kong. Available at http://www.cuhk.edu .hk/ant/PostgraduateForum2011/Arch/NaizatulAkmaMOKHTAR.pdf.

Murillo-Barroso, Mercedes, Thomas Oliver Pryce, Bérénice Bellina, and Marcos MartinónTORRES

2010 Khao Sam Kaeo: An archaeometallurgical crossroads for trans-Asiatic technological traditions. Journal of Archaeological Science 37(7): 1761-1772.

NitTA, EijI

1997 Iron-smelting and salt-making industries in northeast Thailand, in Indo-Pacific Prehistory: The Chiang Mai Papers: 153-160, ed. R. P. Soejono and David J. Welch. Chiang Mai: IndoPacific Prehistory Association, Australian National University.

O’Reilly, Dougald J. W., Angela Von Den Driesch, and Vuthy Voeun

2006 Archaeology and archaeozoology of Phum Snay: A late prehistoric cemetery in northwestern Cambodia. Asian Perspectives 45(2): 188-211.

Piétak, Jean-Pierre, Marc Leroy, Cécile le Carlier, and Paul Merluzzo

2002 Nouvelles données sur l'importance des vestiges de sidérugie ancienne en Puisaye [New research on the importance of ancient iron metallurgy remains in the Puisaye]. Revue Archéologique de l'Es 61:117-131.

Ploquin, Alain

1994 L'analyse chimique en paléosidérugie [Chemical analysis in the paleo iron industry], in $\mathrm{La}$ sidérugie ancienne de l'est de la France dans son contexte européen [The ancient iron industry of Eastern France within its European context]: 16-23. Archéologie et archéométrie: Actes du Colloque de Besançon 11-14 décembre 1993 [Archaeology and archaeometry: Proceedings of the International Symposium, Besançon, 11-14 December 1993]. Paris: Les Belles Lettres.

Ploquin, Alain, Cécile Mahe, Marc Leroy, Nadine Dieudonné-Glad, and Catherine Jarrier

1996 Reconstruction of ironmaking procedure: A progress report about petrographical studies of slaggy wastes from archaeo-ironmaking sites, in The Importance of Ironmaking: Technical Innovation and Social Change: 105-119. Stockholm: Jernkontoret.

Pole, L. M.

1985 Furnace design and the smelting operation: A survey of written reports of iron smelting in West Africa, in African Iron Working. Ancient and Traditional: 142-163, ed. Randi Haaland and Peter Shinnie. Oslo: Norwegian University Press.

Pryce, T. Oliver, Sandrine Baron, Bérénice H. M. Bellina, Peter S. Bellwood, Nigel Chang, Pranab Chattopadhyay, Eusebio Dizon, Ian C. Glover, Elizabeth Hamilton, Charles F. W. Higham, Aung Aung Kyaw, Vin Laychour, Surapol Natapintu, Viet Nguyen, Jean-Pierre Pautreau, Ernst Pernicka, Vincent C. Pigott, Mark Pollard, Christophe Pottier, Andreas Reinecke, Thongsa Sayavongkhamdy, Viengkeo Souksavatdy, and Joyce White

2014 More questions than answers: The Southeast Asian Lead Isotope Project 2009-2012. Journal of Archaeological Science 42:273-294.

Pryce, T. Oliver, Andrew H. Bevan, Roberto Ciarla, Fiorella Rispoli, Cristina Castillo, Brenna Hassett, and Julia L. Malakie

2011 Intensive archaeological survey in Southeast Asia: Methodological and metallurgical insights from Khao Sai On, Central Thailand. Asian Perspectives 50(1-2): 53-69.

Pryce, T. Oliver, Chanthaphilith Chiemsisouraj, Valery Zeitoun, and Hubert Forestier

2011 An 8th-9th century AD iron smelting workshop near Saphim village, NW Lao PDR. Historical Metallurgy 45(2):81-89.

Pryce, T. Oliver, Mitch Hendrickson, Kaseka Phon, Chan Sovichetra, Michael F. Charlton, Stéphanie Leroy, Philippe Dillmann, and Quan Hua

2014 The Iron Kuay of Cambodia: Tracing the role of peripheral populations in Angkorian to colonial Cambodia via a 1200 year old industrial landscape. Journal of Archaeological Science $47: 142-163$.

Pryce, T. Oliver, and S. Natapintu

2009 Smelting iron from laterite: Technical possibility or ethnographic aberration? Asian Perspectives 48(2): 249-264. 
Rehren, Thilo, Michael F. Charlton, Shadrek Chirikure, Jane Humphris, Akin Ige, and Harald

A. VeldhuiJzen

2007 Decisions set in slag: The human factor in African iron smelting, in Metals and Mines: Studies in Archaeometallurgy: 211-218, ed. Susan La Niece, Duncan Hook, and P. T. Craddock. London: Archetype Publications.

Robion-Brunner, Caroline, Vincent Serneels, and Sébastien Perret

2013 Variability in iron smelting practices: Assessment of technical, cultural and economic criteria to explain the metallurgical diversity in the Dogon area (Mali), in The World of Iron: 257-265, ed. Jane Humphris and Thilo Rehren. London: Archetype Publications.

Rostoker, William, and Bennet Bronson

1990 Pre-Industrial Iron: Its Technology and Ethnology. Archaeomaterials Monograph No. 1. Philadelphia: University of Pennsylvania Museum Publications.

SCHMidT, Peter R.

2009 Iron Technology in East Africa: Symbolism, Science, and Archaeology, 2nd ed. Bloomington: Indiana University Press.

SEIDENFADEN, ERIK

1952 The Kui People of Cambodia and Siam. Journal of the Siam Society 39(2):144-180.

SERNEELS, VinCENT

1993a L'apport des analyses chimiques de minerais, scories et produits associés à l'étude de la sidérurgie ancienne [The contribution of chemical analyses of ores, slags and products in the study of ancient iron smelting], in La sidérugie ancienne de l'est de la France dans son contexte européen [The ancient iron industry of Eastern France within its European context]: 75-81. Archéologie et archéométrie: Colloque de Besançon 11-13 Novembre 1993 [Archaeology and archaeometry: Proceedings of the International Symposium, Besançon, 11-13 November 1993]. Paris: Les Belles Lettres.

1993b Archéométrie des scories de fer: Recherches sur la sidérurgie ancienne en Suisse occidentale [Archaeometry of iron slag samples: Research on the old steel industry in Western Switzerland]. Cahiers d'Archéologie Romande 61. Lausanne: Université de Lausanne.

SHINNIE, Peter

1985 Iron working at Meroe, in African Iron Working. Ancient and Traditional: 28-35, ed. Randi Haaland and Peter Shinnie. Oslo: Norwegian University Press.

Suchitta, Pornchai

1983 The History and Development of Iron Smelting Technology in Thailand. Ph.D. diss. Department of Anthropology, Brown University, Providence, RI.

Sutton, John E. G.

1985 Temporal and spatial variability in African iron furnaces, in African Iron Working: Ancient and Traditional: 164-191, ed. Randi Haaland and Peter Shinnie. Oslo: Norwegian University Press.

Thuy, Chanthourn

2010 Report on New Discovery of Forges: Chep-Mluprey 10th to 16th January 2010. Phnom Penh: Royal Academy of Cambodia.

2014 Iron and Stone: Ancient Khmer. Phnom Penh: Royal Academy of Cambodia.

Venunan, Pira

2011 Reconstructing the ninth century AD iron smelting technology in Thailand: An archaeometallurgical study of Ban Khao Din Tai, Ban Kruat, Burirum Province. M.Sc. diss. Department of Archaeology, University College London.

2016 An archaeometallurgical study of iron production in Ban Kruat, lower Northeast Thailand: Technology and social development from the Iron Age to the imperial Angkorian Khmer period (fifth century BC-fifteenth century AD). Ph.D. thesis. Department of Archaeology, University College London.

White, Joyce C., And Elizabeth Hamilton

2009 The transmission of Early Bronze Age technology to Thailand: New perspectives. Journal of World Prehistory $22: 357-397$.

White, Joyce C., and Vincent C. Pigott

1996 From community craft to regional specialisation: Intensification of copper production in pre-state Thailand, in Craft Specialization and Social Evolution: In Memory of V. Gordon Childe: 151-175, ed. B. Wailes. Philadelphia: University of Pennsylvania Museum. 